\title{
Impact cratering - fundamental process in geoscience and planetary science
}

\author{
J K PATI ${ }^{1}$ and W U REIMOLD ${ }^{2}$ \\ ${ }^{1}$ Department of Earth and Planetary Sciences, Nehru Science Centre, University of Allahabad, \\ Allahabad 211 002, India. \\ e-mail: jkpati@yahoo.co.in \\ ${ }^{2}$ Museum f. Natural History (Mineralogy), Humboldt-University in Berlin, Invalidenstrasse 43, \\ D-10115 Berlin, Germany. \\ e-mail: uwe.reimold@museum.hu-berlin.de
}

Impact cratering is a geological process characterized by ultra-fast strain rates, which generates extreme shock pressure and shock temperature conditions on and just below planetary surfaces. Despite initial skepticism, this catastrophic process has now been widely accepted by geoscientists with respect to its importance in terrestrial - indeed, in planetary - evolution. About 170 impact structures have been discovered on Earth so far, and some more structures are considered to be of possible impact origin. One major extinction event, at the Cretaceous-Paleogene boundary, has been firmly linked with catastrophic impact, but whether other important extinction events in Earth history, including the so-called "Mother of All Mass Extinctions" at the Permian-Triassic boundary, were triggered by huge impact catastrophes is still hotly debated and a subject of ongoing research. There is a beneficial side to impact events as well, as some impact structures worldwide have been shown to contain significant (in some cases, world class) ore deposits, including the golduranium province of the Witwatersrand basin in South Africa, the enormous Ni and PGE deposits of the Sudbury structure in Canada, as well as important hydrocarbon resources, especially in North America. Impact cratering is not a process of the past, and it is mandatory to improve knowledge of the past-impact record on Earth to better constrain the probability of such events in the future. In addition, further improvement of our understanding of the physico-chemical and geological processes fundamental to the impact cratering process is required for reliable numerical modeling of the process, and also for the correlation of impact magnitude and environmental effects. Over the last few decades, impact cratering has steadily grown into an integrated discipline comprising most disciplines of the geosciences as well as planetary science, which has created positive spin-offs including the study of paleo-environments and paleo-climatology, or the important issue of life in extreme environments. And yet, in many parts of the world, the impact process is not yet part of the geoscience curriculum, and for this reason, it deserves to be actively promoted not only as a geoscientific discipline in its own right, but also as an important life-science discipline.

\section{The historical perspective}

During the 1960s, geoscience underwent a dramatic revolution, through the advent of plate tectonics and complete reassessment of the internally driven geo-processes active on Earth (e.g., Schubert et al
2001; Oreskes 2003). Barely 50 years later, plate tectonics is still a hot topic, and intricacies of plate movements, deep-Earth heat and mass flow dynamics, earthquake/tsunami/volcanic eruption prediction, the interplay between plate tectonics and climate change, and the question of when in

Keywords. Geoscience; planetary science; natural hazards; impact cratering; Dhala structure. 


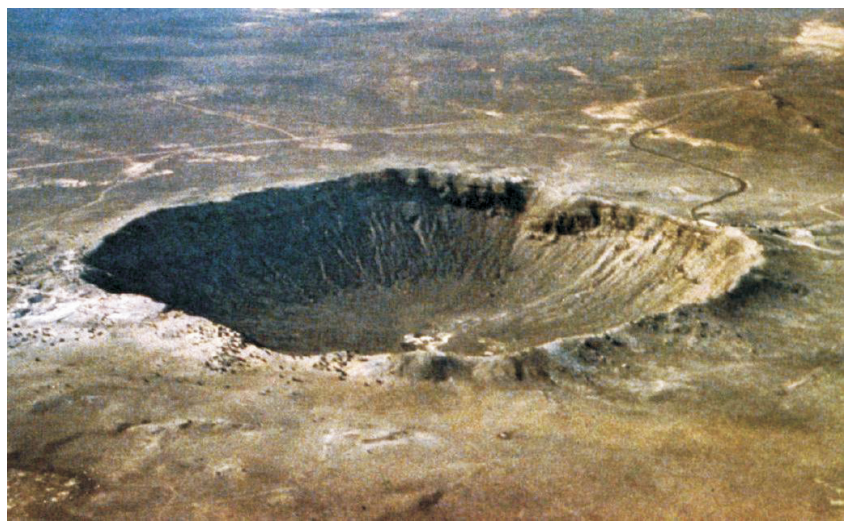

Figure 1. Meteor impact crater (also known as Barringer Crater or, traditionally, Coon Butte), Arizona (USA) a classical impact structure of simple bowl-shape geometry. The crater diameter is $1.2 \mathrm{~km}$ and the impact occurred only 50,000 years ago. (Image courtesy: science_nasa_gov)

the Earth's history did plate tectonics actually start are some of the important issues that are still debated and researched.

Until the mid-twentieth century, only a handful of visionaries had considered large meteorite impact as an essential natural process. These included, for example, the famous German meteorologist Alfred Wegener, well-known for pioneering continental-drift theory (Wegener 1915) and also for his pioneering thoughts about the origin of lunar craters by impact (Wegener 1921). Another early impact proponent was Daniel Moreau Barringer, who was already convinced in the early years of the previous century that the Meteor Crater (figure 1) in Arizona had been caused by meteorite impact (Mark 1987) and considered large meteorite impact as an essential natural process. In 1949, Ralph Baldwin published his seminal volume 'The Face of the Moon', in which he identified crater structures of the Moon as being a result of the impact explosion of extraterrestrial projectiles and drew analogies to some crater structures on Earth (Baldwin 1949). Around the same time, Robert Dietz, also well-known for his contributions to plate tectonics, began to make a case for shatter cones as a reliable recognition criterion for impact structures (e.g., Dietz 1947, 1959).

The decades following World War II, until the late 1960s, however, saw the making of a second revolution in the form of a shift from nearly entirely geocentric science to a Solar System-wide perspective. The first satellites were launched, initially for military and Space Race purposes, then increasingly for civil applications as well. The surfaces of several planetary objects were mapped, and with the Apollo 11 landing on the Moon, Solar Systemwide exploration and scientific analysis had begun.

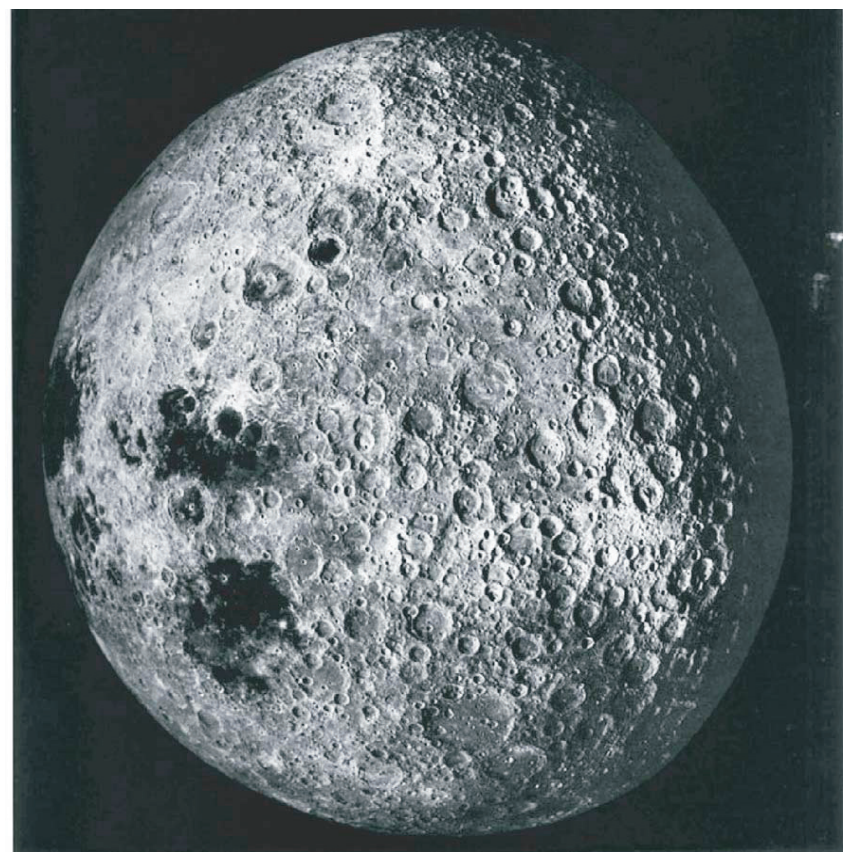

Figure 2. Heavily cratered, ancient highland terrane typical for nearly 85 per cent of the Moon's surface. Photograph by the Apollo 16 crew on their flight back to Earth. A scene like this demonstrates that the lunar surface has been saturated with impact craters, prior to 3.9 billion years ago. The early Earth, at that time, would have certainly looked very similar. (Image courtesy: http: //www. hq. nasa. gov/office/pao/History/SP-362/ch2.html)

This phase led to the realization, initially in just a few countries, that Earth's surface had been subject to bombardment from Space, by large bolide (meteorite, asteroid, comet) impact, which had left its marks in the form of meteorite impact structures (figures 2 and 3). Considering the respective surface areas and gravities of the Moon and Earth, it must be assumed that the Earth would have been subject to a multifold impact bombardment compared to that of the Moon (papers on the topic in, e.g., Grady et al 1998; also Koeberl 2006; Grieve 2006). When the Pioneer and Voyager probes eventually ventured towards the outer limits of the Solar System, it became clear that impact is an essential, fundamental aspect of Solar System-wide, and obviously universal, importance.

Before the beginning of the 1970s, the study of several terrestrial impact structures, in comparison with mineralogical work on minerals in meteorites and later in lunar rocks, had established the important concept of shock metamorphism (e.g., Stöffler 1972; Stöffler and Langenhorst 1994; Langenhorst and Deutsch 1998; French 1998). For example, such early investigations took place at Meteor Crater in Arizona, where remnants of the meteoritic projectile had been found (Shoemaker 1963). Also several 


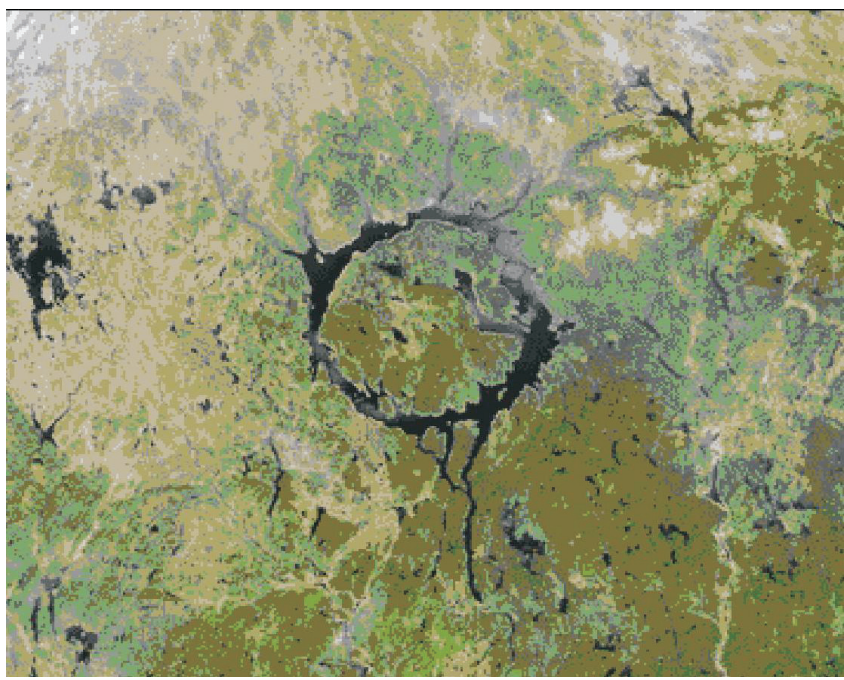

Figure 3. The annular lake of about $100 \mathrm{~km}$ diameter seen in this image delineates the glacially eroded remnant of the Manicouagan impact structure in Quebec, Canada. The near-central elevation represents the remnant of the central uplift structure and is known as Mt. Babel. (Image courtesy: http://craters.gsfc.nasa.gov)

structures in Canada (papers in French and Short 1968) were investigated early on, as well as the Ries Crater in southern Germany (papers in French and Short 1968) and some Russian structures. For a comprehensive albeit somewhat popular review of the history of impact structures, refer to Mark (1987). Regarding shock metamorphism in meteorites, a detailed introduction to shock metamorphic effects in chondrites is, for example, found in Stöffler et al (1991). Also known as impact metamorphism, this involves those mineral and rock deformations that demand extreme pressures and temperatures (generated as the consequence of impact-produced shock compression), as well as ultra-high strain rates (Spray 1998), far in excess of conditions that internally-driven metamorphism could achieve in near-surface environments (e.g., French and Short 1968; Stöffler and Langenhorst 1994; Grieve et al 1996). To give just one example, the recognition of impact deformation in felsic terrestrial rocks typically involves detection of the so-called planar deformation features (PDFs) in rock-forming minerals. PDFs are planar and crystallographically controlled, narrowly spaced (at $2-10 \mu \mathrm{m}$ ), $<2 \mu \mathrm{m}$ wide, microscopic to sub-microscopic 'lamellar' features, which require minimum formation pressures of ca. 8-10 GPa (80100 kbar) (Stöffler and Langenhorst 1994; Grieve et al 1996; Hufmann and Reimold 1996; French 1998).

In recent years, a number of publications have been generated in which the presence of PDFs, i.e., features with planar geometry, has been claimed,

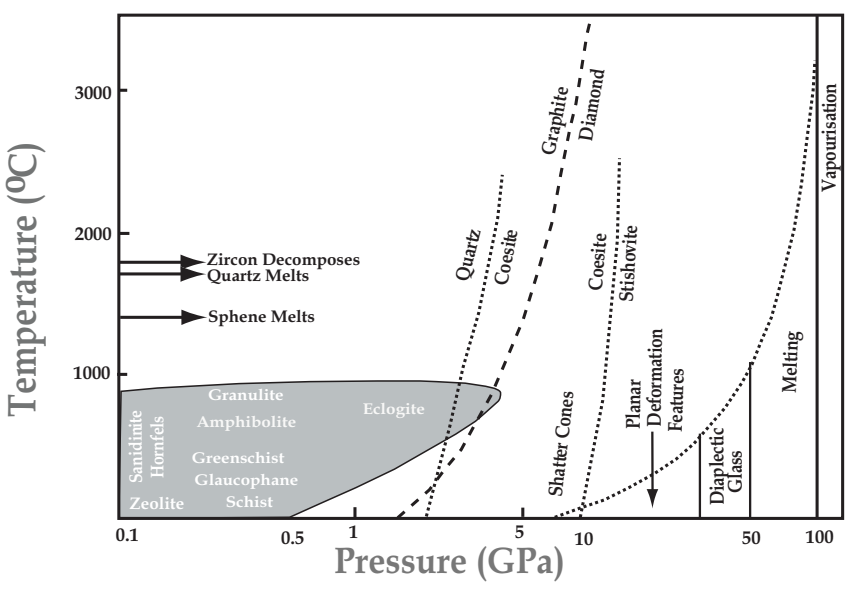

Figure 4. Pressure-temperature plot distinguishing the domains of normal terrestrial metamorphism (with some metamorphic facies marked) and of shock (impact) metamorphism (redrawn after Koeberl 1997). The stability fields of various phases are drawn based on static phase equilibria experiments (after French 1998). The dotted line at right shows approximately the post-shock temperatures produced at certain shock pressures for granitic target rock.

but no such evidence was presented. Admittedly, there are deformation features that may resemble PDFs closely, but thorough scrutiny will reveal that those candidates are not planar - which means that even a slight curvature is a discrediting aspect. It is vital to determine the crystallographic orientations of any candidate's features, especially where the true nature of such features is ambiguous. PDFs are formed mainly along the $\{0001\}\{10 \overline{3} 1\}$ and $\{10 \overline{2} 1\}$ orientations, however these same orientations may also be found for some planar fractures and also some nonplanar features (of uncertain origin), which have indeed been observed in some impact structures as well, where they might represent the low-shock regime of ca. 2-8 GPa. Further work on these crystallographic phenomena, also through low-shock pressure experimentation, is required.

Diaplectic glass (syn., thetomorphic glass) is generated for some major rock-forming minerals including quartz and the feldspar minerals in the shock pressure range between 25 and $35 \mathrm{GPa}$ (e.g., French 1998). For example, the diaplectic glass phase of plagioclase, known as maskelynite, is known from many terrestrial impact structures as well as from meteorites and lunar rocks and is formed at shock pressures of not less than $25 \mathrm{GPa}$ (figure 4).

Transformation of minerals into high-pressure polymorphs, such as that of quartz to coesite and/or stishovite, of graphite to diamond, or of zircon to reidite, or mineral dissociation due to high shock-induced temperatures (e.g., zircon to baddeleyite and silica), related to shock pressures 


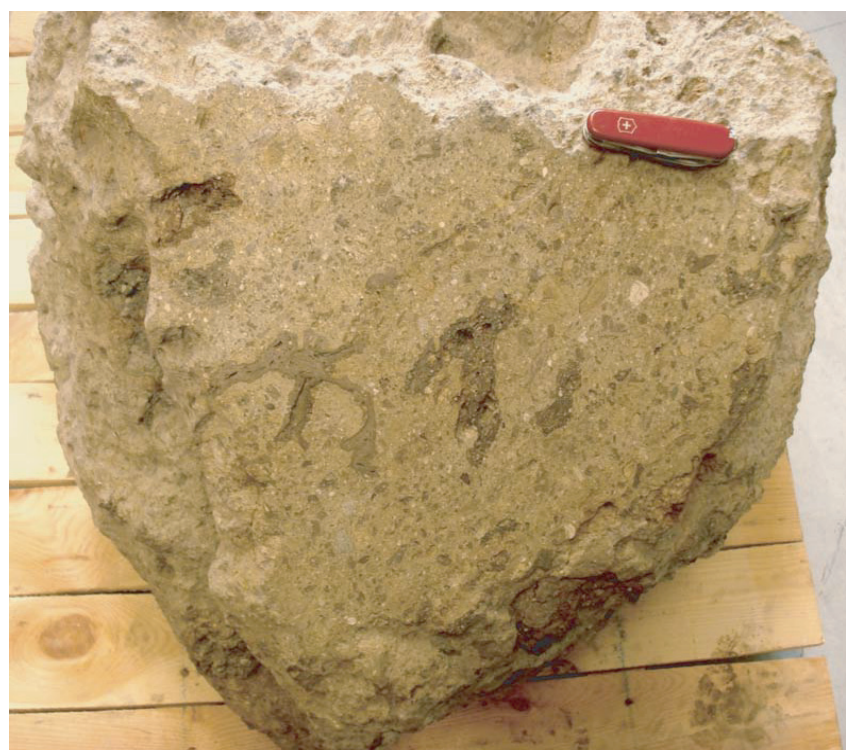

Figure 5. A large piece of suevite (impact breccia with melt fragments in a clastic matrix) from the type locality, the Ries impact structure in southern Germany. Melt fragments are the dark, amoeboid patches on the top. Courtesy ZERIN (= Zentrum für Rieskrater-Forschung in Nördlingen). Pocket knife for scale ca. $9 \mathrm{~cm}$ long.

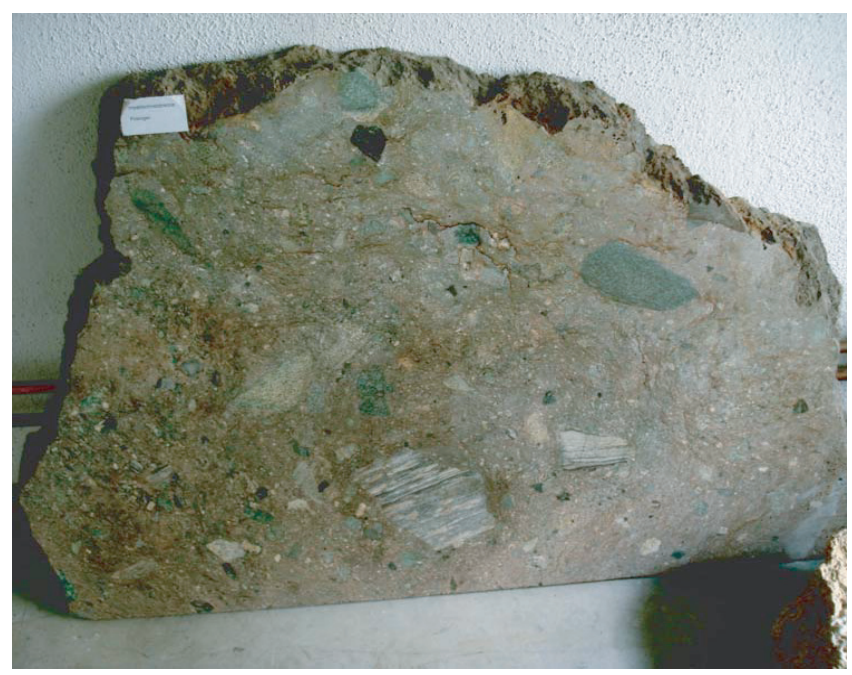

Figure 6. Impact melt breccia from Polsingen, Ries crater. This sample displays a polymict population of target rock clasts set into a finest-grained crystalline melt matrix (Courtesy ZERIN, Nördlingen). Slab about $1 \mathrm{~m}$ in width.

between 15 and ca. $50 \mathrm{GPa}$, may also provide vital clues to impact processes that affected rocks of the uppermost crust. Mineral melting (such as formation of silica glass - lechatelierite) and bulk rock melting are characteristic of the shock pressure regimes between 30 and $45 \mathrm{GPa}$, and between 45 and $>60 \mathrm{GPa}$, respectively.

Macroscopically, a distinct series of impact breccia types of polymict nature has been recognized

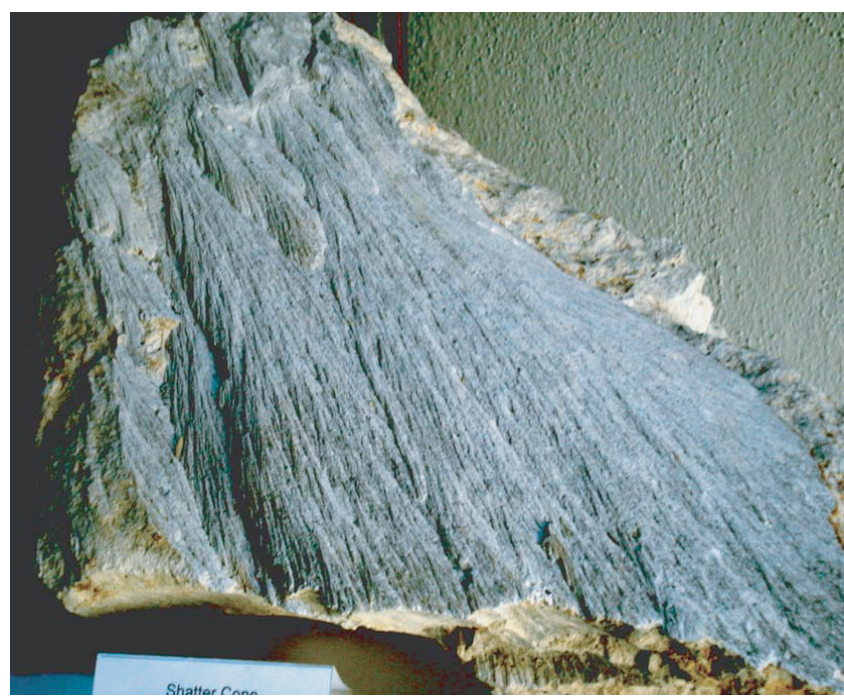

Figure 7. A $30 \mathrm{~cm}$ size (longest dimension) shatter cone from the Steinheim Basin impact crater, southern Germany (Courtesy ZERIN, Nördlingen).

(e.g., Stöffler and Reimold 2006), which includes purely cataclastic breccia, so-called monomict or polymict lithic breccia that traditionally has also been called 'fragmental breccia'. A clastic-matrix breccia with melt fragments is termed suevite (after the type location at the Ries Crater in the province Suevia in southern Germany; figure 5), whereas glassy or crystalline melt-matrix breccia is known as impact melt rock (or impact melt breccia, if the clast content is large; figure 6). Shatter cones (e.g., Wieland et al 2006 and references therein) have been, since Dietz' early work (see above), been recognized as a further macroscopic impact-diagnostic phenomenon (figure 7). In contrast, the notion that pseudotachylite was of impact-diagnostic value, as promoted repeatedly in the recent literature, must be discouraged, as obviously such friction melt is known from numerous tectonic settings. Also, pseudotachylitelike breccias, in the form of veins or complex occurrences, in impact structures comprise a range of melt and clastic breccia types (Müller-Mohr 1992; Reimold 1995, 1998; Reimold et al 2005), and Reimold in these publications encouraged to use the term 'pseudotachylitic breccia' for such materials (figure 8 ) - in impact structures - in order to emphasize the genetic difference to tectonic friction melt (Reimold and Gibson 2005b; Reimold et al 2006). It is obvious though that friction melting could easily be a process active during the various stages of impact cratering (as also shown in shock recovery experiments by Kenkmann et al (2000) and Langenhorst et al (2002), but further work on these impact breccias is still required to differentiate between injection of impact melt, friction melt, friction-plus-shock produced melt, and 


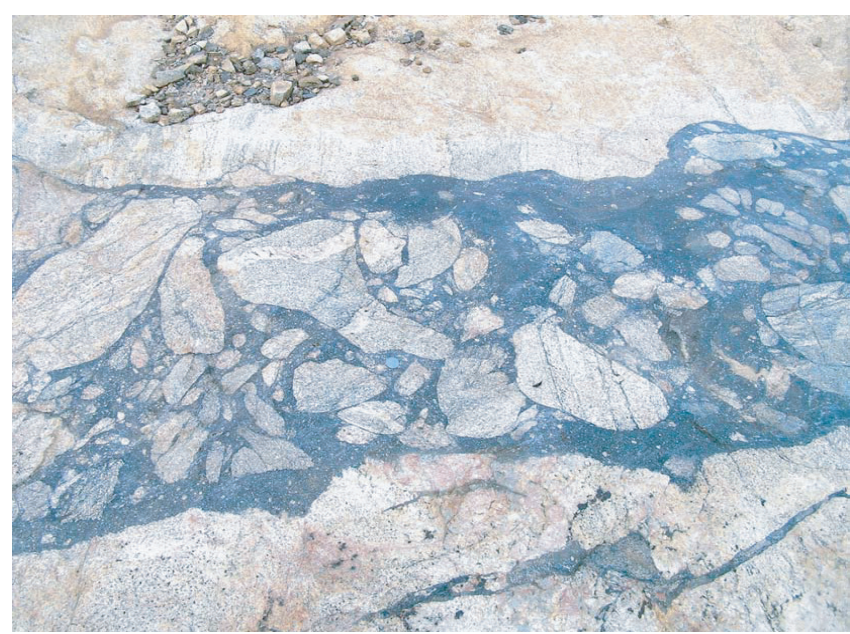

Figure 8. A pseudotachylitic breccia exposure in granitic gneiss at Salvamento Quarry, northern core of the Vredefort Dome. Note the sharp contact to the host rock and the variety of generally well-rounded granitoid clasts. A 2 Rand coin is used as scale and is about $3 \mathrm{~cm}$ wide.

locally produced shock compression melt or melt generated after decompression from peak shock pressure.

Detailed geological analysis of impact structures, in combination with physical and chemical analysis of the products of impact and numerical modeling of the process as a whole, laid a solid foundation for the understanding of the process of impact cratering by the 1990s (Melosh 1989). However, as already shown with various examples, further multidisciplinary study of impact structures is required for improved, comprehensive understanding of this catastrophic process and its effects and products.

\section{What is the current terrestrial impact record?}

Around the middle of the twentieth century not more than about 10 meteorite impact structures had been proven, basically because in all these structures remnants of the bolides had been discovered within or near them. From then on until the 1990s, the impact structure discovery rate evolved exponentially, due to the accessibility of new recognition criteria. Improved geophysical coverage and remote sensing data sets allowed identification of circular structures more easily. By that time, some 160 impact structures had been confirmed through the presence of diagnostic shock deformation features and several others because they contained shatter cones.

A further boost for impact cratering studies was provided by the initially highly controversial, then however widely accepted proposal that the Cretaceous-Tertiary boundary mass extinction involved a catastrophic impact event (Alvarez et al 1980; Smit and Hertogen 1980) that caused a global environmental disaster. For this event the Chicxulub structure in Mexico has since been widely accepted as the 'smoking gun' (Hildebrand et al 1991; papers in Koeberl and MacLeod 2002). With regard to the recent controversy that Chicxulub and the $\mathrm{K} / \mathrm{P}$ impact event could signify the occurrence of two massive impact events in rapid succession, see, e.g., Keller et al (2004). However, this has been rejected most recently by e.g., Arenillas et al (2006) and Schulte et al (2006). The number of confirmed impact structures on Earth, thereafter, has slowly increased further, standing now at about 170 , with several others proposed but not unequivocally confirmed yet. It is important to emphasize that while geophysical observations or remote sensing have been very successful in pinpointing the locations of a number of impact structures, the acceptance of such discoveries as confirmed impact structures has, in all cases, to come from the study of shock-deformed rocks and minerals, or the recognition of traces of a meteoritic projectile in impact melt rock (e.g., Montanari and Koeberl 2000; Muñoz-Espadas et al 2003; Koeberl 2004).

Recently, the ready access to software such as GoogleEarth has led to a proliferation of 'meteorite impact structure' reports, each of which needs to be checked carefully for its merit. This is exemplified by recent reports of possible impact structures received by one of us (WUR) in South Africa, especially about a possible impact structure near the town of Tete in Mozambique and another north of Polokwane in Limpopo Province of South Africa. Both these indications turned out to relate to the locations of well-known carbonatite complexes. Much interest was also received by the suggestion that a large impact structure named Kebira could be located on the Egyptian-Libyan border (El-Baz and Ghoneim 2006), although no ground truth has been obtained to date.

Remote sensing observations can be extremely useful with regard to giving first indications of the existence of previously unknown impact structures. However, conclusions on the impact origin of such features based on superficial observation and, at best, cursory investigation on the ground does not suffice. A good example of this is provided by the report by Paillou et al (2003) about the existence of two 'impact structures', named the Arkenu structures, in Libya. These authors failed to provide shock metamorphic observations that would support this claim, and they also ignored the long known field situation that these sites coincided with carbonatite occurrences (Baegi 1996). Unfortunately, both 'Arkenu 


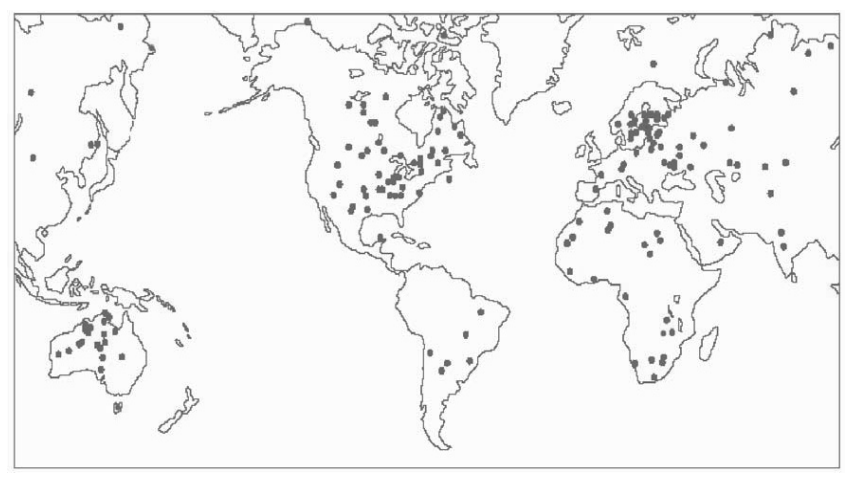

Figure 9. Global distribution of the 172 currently known confirmed terrestrial impact structures (http://www. unb.ca/passc/ImpactDatabase/index.html). The Dhala impact structure in India (arrow) is the latest addition to this map.

structures' have found their way into the terrestrial impact data base of the University of New Brunswick (www.unb.ca/passc/ImpactDatabase/ CINameSort.html, of 2/10/2006). Other websites developed in the past few years (e.g., web.eps.utk.edu/) uncritically list any structure that might have been proposed ever as a possible impact structure. Caution is demanded!

On a global map of the distribution of terrestrial impact structures (figure 9), a majority is found in locations over North America, Eurasia, and Australia. Clearly, there is a link between space exploration (and inherent relatively widespread knowledge about impact structures and their formation) and impact research. In those countries that have been strongly involved in the Space Race and subsequent space exploration, such as the USA and Russia, as well as their allies, large numbers of impact structures have been successfully identified and confirmed. Other countries in Europe, especially in Scandinavia, followed suit due to the interest of small numbers of workers or special research programs by funding agencies. Small groups of impact workers in certain regions (e.g., Australia or South Africa) have been able to make significant local contributions. Without doubt, the television-aided promotion of space-exploration programs in the "western world" attracted significant attention to the impact process as well. The large number of impact structures identified in Australia must be credited to that particular pioneer of impact cratering studies and planetary geology, Eugene M Shoemaker, who for many years together with his wife Carolyn, spent field seasons in Australia searching for and confirming impact structures (Glikson and Haines 2005).

On the African continent, there are two regions with known impact structures: Saharan Africa, where oil exploration between 1950 and 1970 resulted in extensive aerial, later satellite-based, exploration and ground-based geological follow-up that led to the recognition of several impact structures. It does appear, however, that a number of these structures need to be revisited in order to obtain maximum geological information from them and in some cases confirm the actual impact origin. For example, both the BP and Oasis structures in southeastern Libya have only obtained rather short geological attention, and only limited shock petrographic results have been obtained to date (Koeberl et al 2005 and references therein). In southern Africa, a small number of impact workers at the University of the Witwatersrand, generally in collaboration with overseas experts, have been successful in confirming the impact origin of a number of structures, including two of the largest ones in the terrestrial impact cratering record: Vredefort, the world's largest and oldest known impact structure (ca. $250-300 \mathrm{~km}$ original diameter and $2020 \pm 5 \mathrm{Ma}$ old; for a review: Gibson and Reimold 2001) and Morokweng (70-80 km original diameter, $145 \mathrm{Ma}$ old - Reimold 2006). In central Africa, however, there is a wide zone with no confirmed impact structures - due to the dense rainforest in those regions that not only hinders remote sensing investigations, but also ground access for detailed geological and geophysical studies. Another reason for the poor central African impact record must be the highly adverse socio-political conditions that have raged in these regions, especially the large number of civil wars.

South America has a few impact structures and several other possible ones are being investigated, but it has only been in the last few years that the geoscientific community in that continent has taken note of the special importance that impact has had, for this planet and every other solid body in the Solar System.

With the exception of Russia and some other countries of the former USSR, Asia does not have a strong record of impact structures despite the enormous size of the territory of this continent, nor of impact research. For example, China has yet to report a single confirmed impact structure; a proposed so-called Duolon structure (Wu 1987) has long been proposed but never been confirmed. A possible impact structure in the territory of Mongolia is currently investigated (C Koeberl, pers. commun.). Noteworthy Asian exceptions are the Lonar crater (figure 10) in India (Kumar 2005; Osae et al 2005; Chakrabarti and Basu 2006, and older references therein), and the Australasian tektite strewnfield, both of which have attracted much interest amongst researchers. In the latter case, much effort has been expended to identify the source crater for these tektites, believed to be 


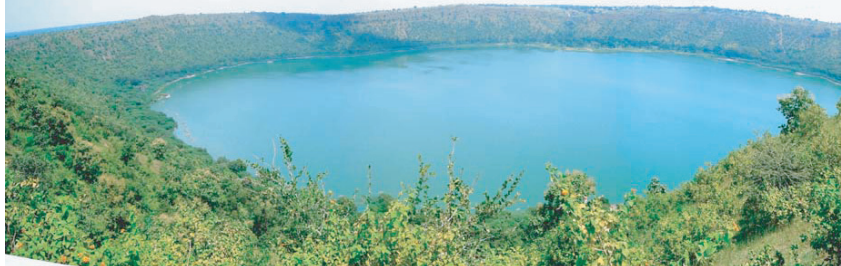

Figure 10. Lonar crater $\left(19^{\circ} 58^{\prime} \mathrm{N}, 76^{\circ} 31^{\prime} \mathrm{E}\right)$, Maharastra, India. Lonar is a rare terrestrial impact structure formed entirely in basaltic target rock. It is a simple, near circular structure with a diameter of $\sim 1.8 \mathrm{~km}$ and an apparent depth of $\sim 150 \mathrm{~m}$

located in southeast Asia (Son and Koeberl 2005 and references therein). The Ramgarh structure in India has also been proposed as an impact structure by Sisodia et al (2006a, b), but no supporting shock metamorphic evidence has been reported to date and thus, this claim has remained controversial (Reimold et al 2006).

However, a new impact structure has indeed been identified on the north-central Indian subcontinent - the Dhala structure of perhaps as much as $15 \mathrm{~km}$ diameter (Pati 2005; Pati et al 2006a, 2006b; figure 11). This circular structure is centered at $25^{\circ} 17^{\prime \prime} 59.7^{\prime} ; 78^{\circ} 8^{\prime \prime} 3.1^{\prime}$ on the central Indian Bundelkhand craton, Shivpuri District, Madhya Pradesh, India. It is a complex structure with a well-defined central uplift. The target rocks are a coarsely crystalline granitoid of Archean age $(\sim 2.5 \mathrm{Ga})$ that is overlain by Vindhyan Supergroup rocks of Paleoproterozoic age. The circular outcrop pattern, occurrence of rings of extensive monomict granitoid breccia, presence of diagnostic shock metamorphic features such as planar deformation features (PDFs) in quartz (figure 12) and feldspar, and ballen textured quartz (figure 13) have unequivocally established the impact origin for Dhala (Pati 2005; Pati et al 2006a, 2006b). The age of this new structure is currently only loosely constrained by the age of the $2.5 \mathrm{Ga}$ target granitoid and the about $1.6 \mathrm{Ga}$ old Vindhyan cover strata, but in all likelihood this newly proven impact structure will be recorded as one of a mere handful of Proterozoic and Archean impact structures.

Generally, the geoscientific community has been rather slow in recognizing the importance of impact for many disciplines (see below). Only in the last decade have chapters been dedicated to the physical and chemical processes related to impact, and geological aspects of impact structures, entered new textbooks and university lecture series. In a country like South Africa, where a strong effort has been made for more than 15 years to spread the word about impact, both in scientific and popular literature, and where several outstanding impact

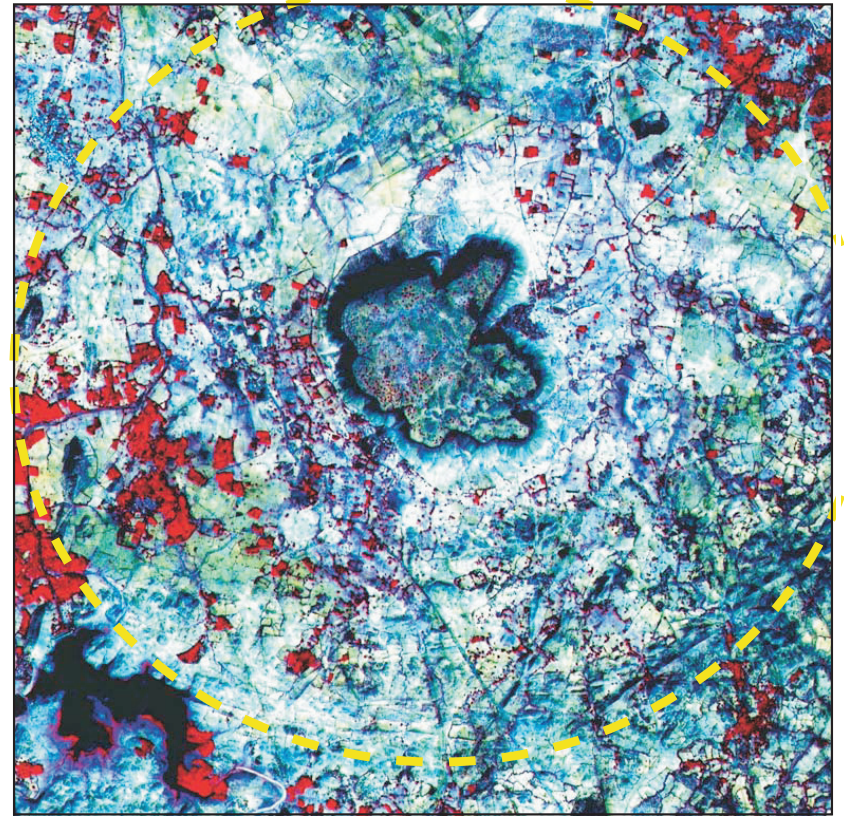

Figure 11. Indian Remote Sensing False Colour Composite image of the recently discovered Dhala impact structure, Shivpuri district, Madhya Pradesh, India, of possible Paleoproterozoic age (Pati 2005). It is an eroded remnant of a complex structure with a central uplift and a diameter of $\sim 15 \mathrm{~km}$. The outer limit of the Dhala structure based on so far available data is shown with a dashed yellow line.

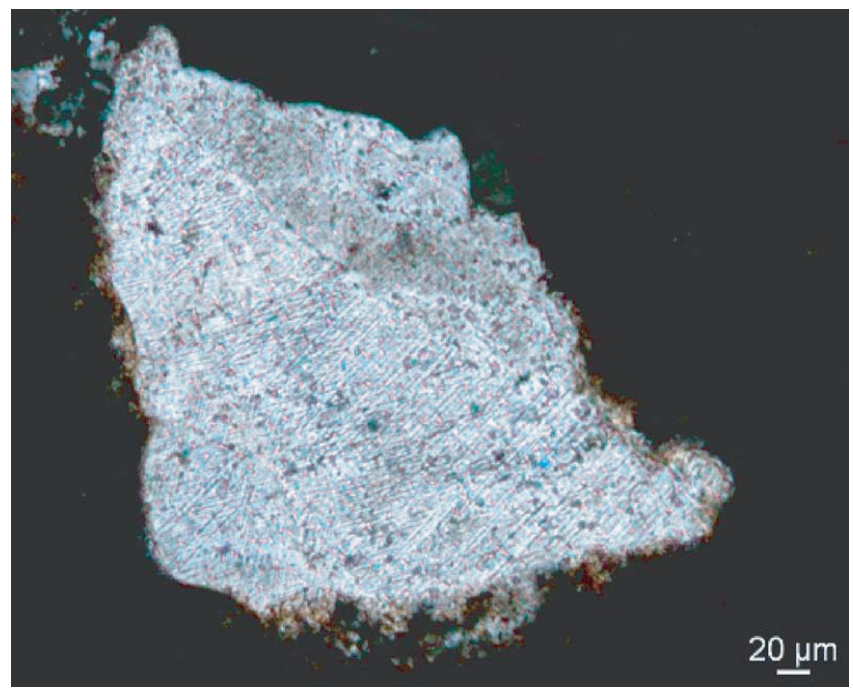

Figure 12. Shock-characteristic closely-spaced shock microdeformation features (planar deformation features, PDFs) in a quartz grain of an impact melt breccia sample from the Dhala impact structure. At least three sets of PDFs are clearly observed and a preliminary estimate of $20 \mathrm{GPa}$ shock pressure can be assigned to this grain.

structures are awaiting scientific as well as lay visitors (Reimold 2006), the major part of the population and some geologists are still ignorant about the importance of this process. It took the World Heritage's declaration of a part of the central uplift 


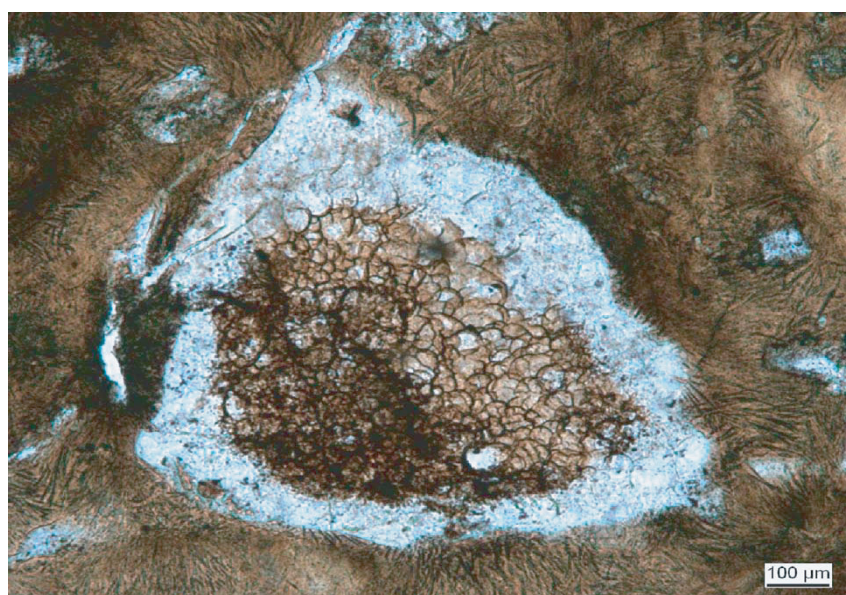

Figure 13. Characteristic ballen texture is observed in a quartz clast in an impact melt breccia sample from the Dhala area. Annealing of diaplectic glass leads to densification of the glass between 700 and $1200^{\circ} \mathrm{C}$ and to complete recrystallization to alpha-quartz + alpha-cristobalite above $1200^{\circ} \mathrm{C}$ (Grieve et al 1996). This transformation leads to the production of the characteristic "ballen" texture in impact melt rocks. Note the intricate devitrification texture of the melt matrix.

structure of the world's largest and oldest known impact structure, the Vredefort Structure, of July 2005 to refocus some attention of the public onto impact (Reimold and Gibson 2005a, 2006).

\section{Stratigraphic impact evidence}

Besides impact structures themselves, a number of impact layers have now been recognized on Earth, some, such as the global Cretaceous/Tertiary $(\mathrm{K} / \mathrm{T}$; recently renamed Cretaceous/Paleogene $\mathrm{K} / \mathrm{P}$ ) boundary layer (Smit 1999), linked to a source crater (in this case the Chicxulub structure in Mexico), others without any relation to possible sources. There are several so-called spherule layers (figure 14) known from the Archean Barberton Greenstone Belt and within the Proterozoic Transvaal Supergroup of South Africa, as well as from the Archean Pilbara craton and the Hamersley basin of western Australia, which were deposited around 3.4 and at about $2.2 \mathrm{Ga}$ (Simonson and Glass 2004, and references therein; Hofmann et al 2006). Chemical and isotopic evidence, particularly enrichment of platinum group elements and $\mathrm{Cr}$ isotopic data, has shown that these strata contain meteoritic material and, thus, must be of impact origin (Simonson and Glass 2004). Some aspects of these ancient impact ejecta, such as - exactly how many impact ejecta layer occur in the stratigraphy of the extensively deformed Barberton terrane, and why the Ir concentrations in some of the analysed samples are as high, or even in

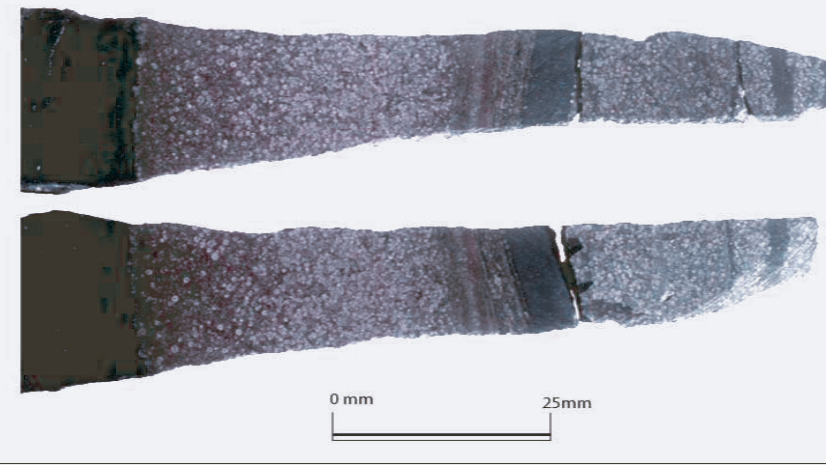

Figure 14. A ca. $12 \mathrm{~cm}$ long sample of multiple spherule layers (S3/S4 - compare Hofmann et al 2006), intercalated with several shale bands, from the Archean Barberton Greenstone Belt. First proposed to be of impact origin based on very high Ir abundances in the spherule bands, this has since been confirmed through $\mathrm{Cr}$ isotopic analysis (see text for detail). Petrography and geochemistry of this sample were discussed by Koeberl et al (1993).

excess, of $100 \%$ meteoritic component, despite the fact that these materials are not primary deposits but represent reworked and diluted sedimentary layers, and even whether some of the accretionary lapilli layers in the Barberton stratigraphy could also represent impact ejecta (Hofmann et al 2006) remain to be clarified through further research. In addition to bearing witness to the oldest known impact events on this planet, these spherule layers provide information about the nature of the early crust on Earth, and about the environmental processes set in motion as a consequence of these impact events. Considering the overall paucity of Archean crust on this planet, such information may go a long way to elucidate the processes that affected our planet early in its evolution.

No impact ejecta from the oldest known impact structure on Earth, the Vredefort impact (Gibson and Reimold 2001), have yet been confirmed. It is thought that they may exist at the base of the Waterberg Group in South Africa, a thick sequence of sedimentary strata, the age of which has been gradually increased and may now be close to (or even equivalent to) the $2.02 \mathrm{Ga}$ age of the Vredefort event (G Brandl, Polokwane, South Africa, pers. commun.; also Maré et al 2006). A thick spherule layer in southern Greenland of about 1.8-2.0 Ga age was tentatively linked with either the Vredefort impact or with the Sudbury event (Chadwick et al 2001). The Sudbury impact structure (estimated $250 \mathrm{~km}$ diameter, $1850 \mathrm{Ma}$ old) is located in Ontario (Canada) and was formed in the Superior Province. It would help if the paleopositions of the Kaapvaal Craton and the Superior Province landmass could be constrained with respect to the then position of southern Greenland. 
Recently, impact ejecta deposits have been identified in Ontario and Minnesota (Addison et al 2005) and in Michigan (Kring et al 2006) that have been linked stratigraphically with the Sudbury Structure.

Several other strata in the Phanerozoic, associated with mass extinctions, have been tentatively linked with impact (e.g., review by Simonson and Glass 2004), but to date the confirmation that mass extinctions in the late Ordovician, late Devonian, at the Triassic/Jurassic or Jurassic/Cretaceous boundaries, and in the late Eocene (Farley et al 1998) could be related to impact is still outstanding. In particular, there has been widespread debate of a possible link between the "Mother of All Mass Extinctions" at the Permian/Triassic boundary (P/Tr; $251 \mathrm{Ma}$ ago [Gradstein et al 2004]; e.g., Retallack et al 1998; Becker et al 2001, 2004; Kaiho et al 2001; Koeberl et al 2002; Renne et al 2004) and impact, and a number of possible impact sites for this hypothetical event have been promoted. First there was a suggestion that an alleged $120 \mathrm{~km}$ wide impact structure in Australia could be the smoking-gun (Mory et al 2000), but Woodleigh turned out to be too small (at $60 \mathrm{~km}$ diameter; Reimold and Koeberl 2000) to have caused a global catastrophe that could have wiped out some $90 \%$ of all life forms. Also the age of Woodleigh changed first a $\mathrm{P} / \mathrm{Tr}$ boundary age was favored (Mory et al 2000), which was followed by a revision to a late Devonian age (Uysal et al 2001) (conveniently also a time associated with a major mass extinction). The revised age for Woodleigh, which is based on $\mathrm{K}$-Ar dating of illitic clays, is, however, as controversial (Renne et al 2002) as the earlier reported $\mathrm{P} / \mathrm{Tr}$ age. Next came the widely debated report that the so-called Bedout Structure on the Ontong Plateau in the Roebuck Basin north of Australia could be the smoking-gun for the $\mathrm{P} / \mathrm{Tr}$ catastrophe (Becker et al 2004), but the very existence of a large, seemingly somewhat circular structure there and an age for an associated melt rock (impact or volcanic in origin) of allegedly $250 \mathrm{Ma}$ were critically received (e.g., Renne et al 2004; Müller et al 2005). The conclusion that Bedout could represent an impact structure has remained contested. The alleged presence of shock metamorphosed quartz at an Antarctic P/Tr boundary site has also not survived scrutiny (Langenhorst et al 2005). Thus, to date, most of the impact cratering community only recognizes the link between large-scale impact and the $\mathrm{K} / \mathrm{P}$ boundary mass extinction. And yet, further work on the $\mathrm{P} / \mathrm{Tr}$ boundary is required, both from a paleontological and a mineralogical/geochemical view.

Notably, only a handful of impact ejecta layers, including the tektite strewn fields, have been identified to date in the Phanerozoic stratigraphic record (see review by Simonson and Glass 2004). Search for spherule layers in these sedimentary sequences could provide important information regarding the past impact flux - especially regarding the frequency of very large events of potential extinction-magnitude. In this regard, it is also still debated what threshold magnitude an impact event ought to have before it could trigger a mass extinction of regional or global importance. Clearly neither the ca. $80 \mathrm{~km}$ diameter Chesapeake Bay (USA) nor the about $100 \mathrm{~km}$ diameter Popigai (Russia) or Manicouagan (Canada) impact structures are related to a mass extinction event, but the $200 \mathrm{~km}$ diameter Chicxulub structure in Mexico is, with this event having occurred into a target of possibly particularly lethal composition (involving a large volume of anhydrite).

\section{The multidisciplinary nature of impact cratering studies}

As mentioned above, geophysical and remote sensing studies have, in recent decades, been instrumental tools for the initial recognition of many impact structures. This is especially true in those cases, where geophysical anomalies were further investigated by drilling for their possible economic value (see below). However, a somewhat circular anomaly does not make an impact structure, as, for example, volcanic features such as kimberlite diatremes, volcanoes, intrusions or extrusions, or collapsed volcanic features, sinkholes, glacial and other erosion features can also be of circular shape. Groundtruthing is required in every suspect instance, and without bona fide shock metamorphic and/or meteoritic-chemical evidence such a structure may not be identified as a 'confirmed impact structure', at best as a 'possible impact structure'. Ground-based geological analysis is also mandatory in order to establish the processes involved in the formation and evolution of an impact structure. Quite some geological detail has been accumulated for both simple bowl-shaped and larger, complex (with central uplift or peak ring) impact structures, allowing rather good approximation of the impact process from the contact (of the projectile with the target) to the final modification phase, by numerical modeling. However, there are still many unresolved geological issues that have not been dealt with adequately, due to the fact that most impact structures are not completely preserved or are partially-to-completely covered by post-impact deposits. In particular, more detailed multidisciplinary research is required on impact structures formed in sedimentary strata. The structural aspects of crater formation and modification, 
as well as the role of porosity and volatiles in target strata are not yet fully understood.

Mineralogical and geochemical studies of impact breccia deposits, in combination with geological investigation of their spatial distribution, are still required to refine our understanding of their formation, depositional processes, and post-impact alteration. Since several years the International Continental Scientific Drilling Program (ICDP) has undertaken large-scale drilling projects always in conjunction with detailed pre-drilling geophysical analysis - at Chicxulub (Mexico), Bosumtwi (Ghana) and Chesapeake Bay (USA), with the aim to provide complete cross-sections through impact breccia fills of these structures (e.g., Stöffler et al 2004; Urrutia-Fucugauchi et al 2004; Gohn et al 2006). A further ICDP impactdrilling project will soon take place at El'gygytgyn crater (18 km diameter, $3.5 \mathrm{Ma}$ age) in northeastern Siberia. The lake deposits there are expected to provide an important paleo-climatic record for the high latitudes, as well as new insights into the impact process affecting a mafic volcanic terrane. It is interesting to observe that in all cases of already completed deep boreholes into complex impact structures, the core obtained did not match the pre-drilling expectations - despite detailed site studies. This demonstrates that our understanding of impact crater geology is still incomplete.

The chronological record of terrestrial impact structures is also still very limited, with many structures not having been dated at all or only constrained by stratigraphic/biostratigraphic means. The terrestrial impact crater database kept at the University of New Brunswick (www.unb.ca/passc/ImpactDatabase/) currently lists 172 impact structures, of which only about $30 \%$ have well-constrained radiometric ages (only those ages with error limits at a maximum of a few Ma were counted). Only a small number of impact structures have been dated by U-Pb TIMS (thermal ion mass spectrometry) or SIMS (secondary ion mass spectrometry) analysis of single zircon crystals from impact melt bodies or massive pseudotachylitic breccia; in addition, some good argon chronological results are available as well. Limitations on this impact chronological database reflect on the precision of impact statistics, i.e., projecting the probability of future impacts of various catastrophic strength from the past impact record. Many studies have also attempted to analyze potential links between the impact crater age statistics and periodicities, speculating at length about the likely astronomical processes that might be responsible for periodic increase in the projectile flux (e.g., Rampino 1999). Efforts ought to be made to continue with high-resolution dating studies on impact melt breccia.

Equally limited is the information available about the nature of the respective projectiles (e.g., Palme 1982; Koeberl 2002; McDonald 2002; Tagle and Claeys 2005). At present, projectile traces have been identified for a limited number of impact structures, and for only part of those could projectile types be determined.

Following the debates about the now confirmed link between impact and the $\mathrm{K} / \mathrm{P}$ boundary and associated mass extinction, and the hypothetical link between impact and other mass extinctions in the Phanerozoic, many paleontologists, stratigraphers, and sedimentologists have taken note of the importance of impact throughout Earth evolution. Unfortunately, many geoscientists in the developing world still do not have regular access to the wider geoscientific literature and, thus, have missed out on this development. It is, however, critical that the entire geoscientific community is knowledgeable about impact cratering, to ensure that the next generation of students is fully educated about this fundamental process. Whereas the $\mathrm{K} / \mathrm{P}$ impact ejecta have been documented world-wide, from New Zealand to South America, central Europe and North Africa, to North America (e.g., papers in Koeberl and MacLeod 2002 and references therein), it can be estimated that catastrophic impact events of this or even larger magnitude could have taken place at a rate of 1 in 50 to 100 million years throughout the Phanerozoic (Chapman and Morrison 1994; see also Chapman 2004). The globally deposited fallout from these events is contained in the stratigraphic rock record - as well as that caused by many more, smaller impact events of continental or regional importance. It is essential that sedimentologists and stratigraphers are alert to the possibility that impact deposits could be encountered in the rock record, as any new discovery will significantly contribute to our overall knowledge about impact flux onto this planet.

Finally, there has been much interest lately in investigations of possible transfer of life from planet to planet, of the influence that giant projectiles onto Earth might have had in creating environments conducive to development and evolution of life, and the recognition that catastrophic impact has disrupted life evolution on this planet at times (at least once confirmed, at the $\mathrm{K} / \mathrm{P}$ boundary) - with mass extinction of numerous species and subsequent renewed evolution (and likely rapid diversification) (e.g., MacLeod et al 1997; Erwin 2001). This has spawned numerous studies of formation and preservation of life in exotic places, and into the possibility that life forms could survive 
through catastrophic impact events. This important and exciting work has become an integral part of still broader astrobiology programs (Norris and Stootman 2004). A vital aspect of the recent ICDP drilling into impact structures has been the sampling for microbial life in the interior of these structures and for analysis of the essential fluids in these settings (e.g., Cockell and Lee 2002).

Thus, it must be concluded that impact cratering studies have become an integral part of many disciplines and multidisciplinary research efforts, on the terrestrial and planetary geology scales alike.

\section{Impact cratering - an integrated discipline}

To compile a list detailing the multifold importance of large bolide impact requires a broad perspective of many of the essential aspects of geoscientific research. Impact processes have taken place throughout the Solar System - and beyond, ever since the elementary accretion process began. There, tiniest particles impacted onto each other and could stick to each other; gradually, impactbuildup of larger and larger planetesimals and planetary bodies could progress (Taylor 1992). That impact is not only a process of the past, but could be very much part of the present in the universe was demonstrated in July 1994 with the successive impacts of small fragments of comet Shoemaker-Levy 9 (Boslough et al 1994) into the atmosphere of the 'Gas Giant' planet Jupiter - in front of the eyes of billions of television viewers. Small fragments, estimated not larger than about $150 \mathrm{~m}$ diameter, of this comet generated enormous explosion plumes and holes in the atmosphere of Jupiter, into which planet Earth would have fit snugly.

Any surface image of the Moon, Mars, or Mercury, those terrestrial planets that essentially lack a dense atmosphere and allow detailed surface exploration, demonstrates (figure 15) how dominant impact cratering has been as a surfacegeological process, ever since the formation of earliest planetary crust more than 4.4 billion years ago. Impact-stratigraphic analysis of particularly the lunar surface has shown that the main part of this bombardment occurred prior to 3.8 billion years ago (with or without a terminal cataclysm as still debated), and since then has exponentially decreased. The fact that Earth is several times larger than the Moon, and its gravitational attraction much higher as well, can only mean that Earth must have endured an even stronger bombardment than our planetary neighbour (Grieve et al 2006; Koeberl 2006).

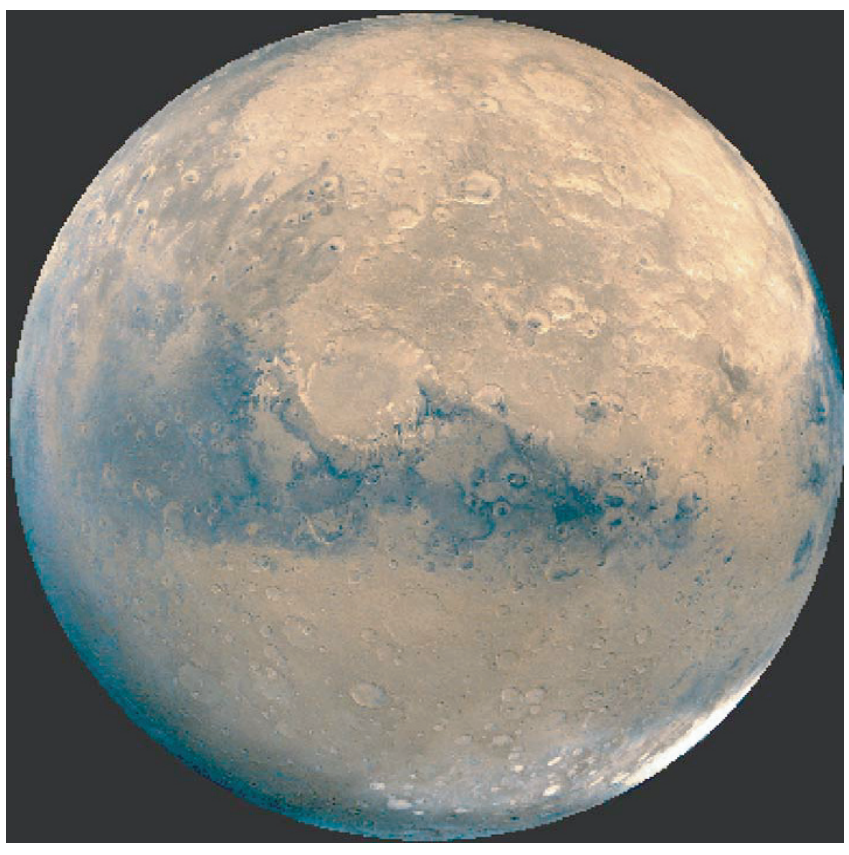

Figure 15. A huge impact structure (Schiaparelli crater, $461 \mathrm{~km}$ diameter, just off the center of the image) on Mars. This photograph of Mars of February 3, 1996 is from the APOD archive. (Credit: NASA, Viking, USGS; http://www.jpl.nasa.gov)

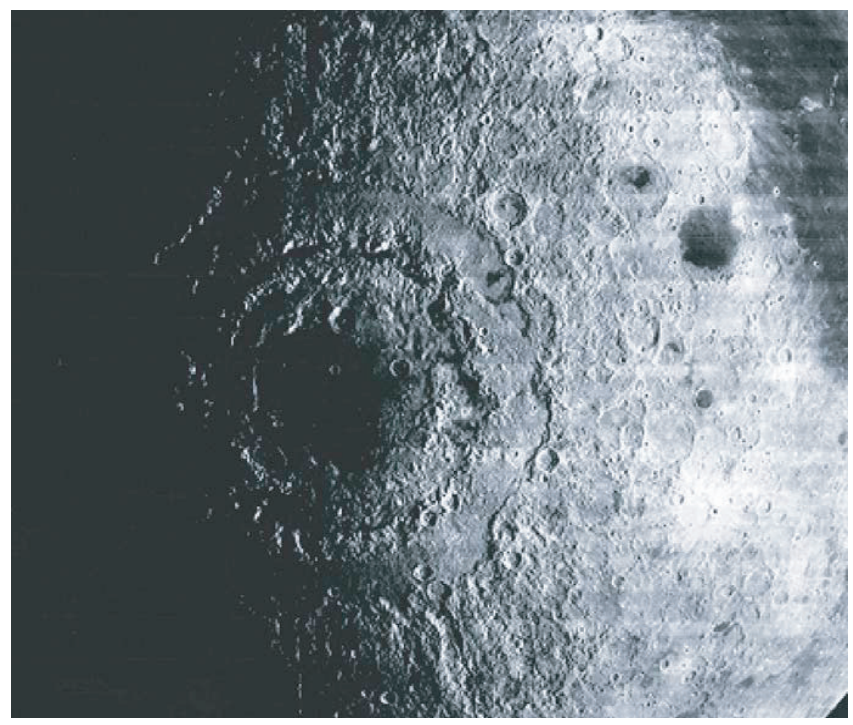

Figure 16. Mare Orientale is one of the gigantic multiring impact basins on the Moon that are all thought to have formed prior to 3.8 billion years ago. The outermost major ring feature, after Wilhelms (1987), has a diameter of $930 \mathrm{~km}$. (Credit: NASA, Lunar Orbiter 4; http://antwrp.gsfc.nasa.gov/apod/ap 960112.html)

Enormous impact events, such as those that resulted in the gigantic multi-ring impact basins (figure 16) on the Moon, in the earliest million years of our Solar System transferred 
immeasurable amounts of kinetic energy onto the proto-planets. In fact, the preferred hypothesis for the origin of the Moon has been, for the last 30 years, the so-called Giant Impact Theory (Cameron and Ward 1976; Hartmann and Davis 1975; Canup 2004a, 2004b), which proposes that a Mars-sized body obliquely impacted the protoEarth at about $4.4 \mathrm{Ga}$ ago, with the result that much of the projectile mass combined with some terrestrial mass to form the proto-Moon (Morishima and Watanabe 2004). Such enormous events transferred their kinetic energy in the form of thermal energy onto the young planets. This, together with the then much enhanced heat flow from radioactive decay of ${ }^{26} \mathrm{Al}$ and other isotopes would have led to substantial melting on the early planets, as promoted in the Magma Ocean hypothesis (regarding the early evolution of the Earth, see e.g., Halliday 2006 and references therein). Thus, impact would have been of decisive effect in the earliest stages of planetary development.

That no body in the Solar System has escaped bombardment has become clear through the recent asteroid and comet missions of NASA, which illustrated that even the nuclei of comets, such as Wild 2 (Stardust mission; Brownlee et al 2003) or Tempel 1 (Deep Impact mission; A'Hearn et al 2005) are seemingly heavily cratered (figure 17). These missions were designed, inter alia, to obtain crucial information about the interior make-up of comets, essential requirement to model impact of such low-density bodies onto planetary surfaces, and to investigate protective measures against future impact catastrophes by such bolides.

An important aspect of the discussion about the onset of life development on Earth has been the role that water, one of the essential ingredients for the formation of life on this planet (for discussion of origin of life on Earth and Archean evidence for early life, see e.g., Westall et al 2006; Schopf 2006, and references therein), must have played, from the start. Was water readily available on the Hadean/Archean planet Earth? How did it originate there? Is it possible that bombardment with a barrage of cometary bodies would have brought sufficient amounts of this life-sustaining resource onto Earth? In other words, is it possible that only through impact terrestrial life could have been spawned - as well as decisively altered, as discussed earlier? In this context, it must also be examined what the chances are that primitive life could have been transferred between planetary bodies - such as between Mars and Earth. Since the 1990s, controversy over whether textural evidence in the Martian meteorite ALHA 84001 would represent traces of organic activity ('early life') (e.g., McKay et al 1996; Treiman 1998), the idea known as 'Panspermia' (Arrhenius 1903; Gladman

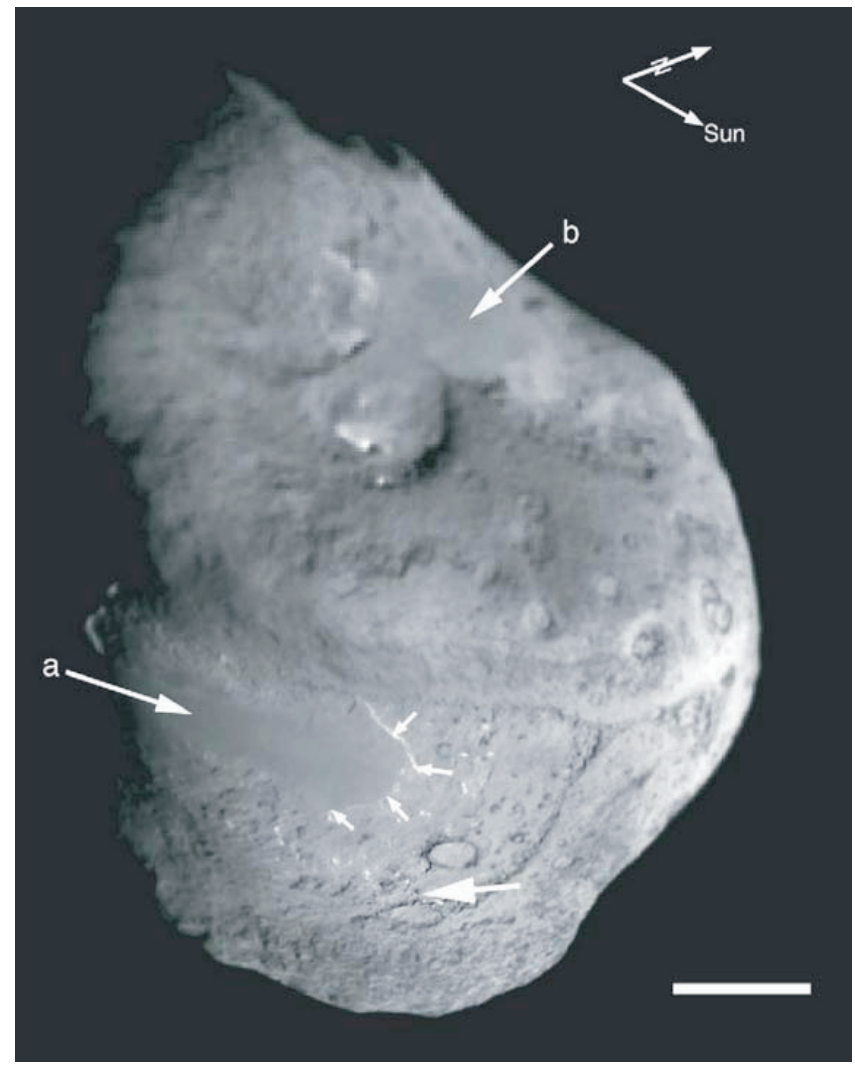

Figure 17. Apparently heavily cratered surface of comet Tempel 1 (the target of the 2005 Deep Impact Mission). This comet was discovered in 1867 by German astronomer, Ernst Wilhelm Leberecht Tempel. The arrows, a and b, point to smooth regions and the large arrow indicates the site of the Deep Impact impact. A scarp is highlighted by small arrows. The scale of the composite image is $1 \mathrm{~km}$. Celestial north is shown near the rotational pole. (Credit: http://solarsystem.nasa.gov/multimedia/display.cfm? $\left.\mathrm{IM}_{-} \mathrm{ID}=4043\right)$

et al 2005) also became popular, namely the possibility that widespread fertilization of the universe took place through impact. In the past few years, initial impact experiments with targets that had been impregnated with primitive life forms, such as spores or microbes, have shown that even the effects of $50 \mathrm{GPa}$ shock experiments could be survived by a significant proportion of the 'target life' (Stöffler et al 2006). Although the role of longer pressure pulses than the exceedingly short shock pulse rates achieved in shock experimentation and of post-impact thermal overprint still need to be further investigated.

The catastrophic influence that impact catastrophes have had on terrestrial life has been discussed above. However, that impact events do not only have to be understood as catastrophes and, in fact, can have true benefits for humankind, must also be examined. Considering the fact that the surfaces of other planetary bodies (e.g., the Moon or Mars) 
largely consist of a thick layer of impact debris (the so-called regolith), and asteroids also have suffered multiple impact events and impactite formation, demonstrates that extraterrestrial impactites must be regarded as possible construction materials, and even oxygen sources, for interstellar development and settlement. Closer to home though, numerous terrestrial impact structures have become recognized as important ore deposits (e.g., Grieve 2005; Reimold et al 2005). Essentially three types of impact-related ore and hydrocarbon deposits have been distinguished:

(1) 'Progenetic deposits' are those that involve pre-impact ore deposits that, however, have been modified or uplifted as a result of large impact events, and only in this way have become exploitable. Examples for this type are the Carswell uranium and Ternovka (Krivoi Rog) iron-ore deposits, respectively (Reimold et al 2005). The detrital gold and uranium deposits of the South African Witwatersrand basin, which represents the outer part of the Vredefort impact structure (Gibson and Reimold 2001; Reimold et al 2005) - also fall into this category (but compare section (3) with regard to the Witwatersrand).

(2) Ore formations that formed as a direct effect of impact would be considered 'syngenetic deposits', for which the Sudbury nickel and PGE resources are a type example. While the elemental wealth already existed in the target region prior to the impact, it was only the impact catastrophe that facilitated formation of sufficient melt, from which the enrichment of the resource could progress.

Impact-derived diamond and lonsdaleite occur in abundance in the Popigai structure in northern Siberia (Masaitis 1998; Grieve and Masaitis 1994), but also have been described in small amounts from other impact structures. It has even been mooted that the carbonado riches of Central Africa and those parts of South America that were part of this region prior to the break-up of Gondwana could have been formed in a catastrophic impact event in the Ubangui basin of the northern Congo and the Central African Republic. However, to date no evidence for the existence of such a large impact structure in those parts has been provided.

(3) Post-impact epithermal/hydrothermal activity leads to the formation of 'epigenetic deposits', known in many impact structures. For example, it is believed that the $\mathrm{Pb}-\mathrm{Zn}$ mineralization in the Siljan impact structure is the result of this process. Economically of much greater significance, however, is the authigenic gold mineralization in the Witwatersrand basin, which is believed to be the result of fluid flow away from the central parts of the Vredefort impact structure, with these hot fluids having dissolved allogenic gold in the Witwatersrand sediments, which was followed by redeposition - and local enrichment - of the resource (Hayward et al 2005; Reimold et al 2005). Extensive hydrocarbon (natural oil and gas) resources have been found and exploited in impact structures, mostly in North and Central America. Grieve (2005) estimated that annually hydrocarbons to the value between 5 and 21 billion US dollars are extracted from such deposits. The Ames Structure in Oklahoma, several sites in the Williston Basin straddling the border between the USA and Canada, the Barrow and Sikulik fields in the environs of the Avak Structure Sikulik gas fields in Alaska, and the extensive breccia deposits of the Campeche oil field in Mexico that has been related to the deformation caused in the environs of the Chicxulub Structure are some of the locations of major producing impact structures (Grajales-Nishimura et al 2000).

With such a wealth of impact-generated ore deposits known already, can any country, especially in the economically needy developing world, afford not to take note of these possibilities? Clearly, the next generation of geologists and exploration staff ought to be aware of the impact process and its possible benefits.

And there are still other positive spin-offs from the study and exploration of impact structures, which may be immensely useful, even if they do not provide immediate revenue like impact-related ore deposits. A number of impact structures, both well preserved and comparatively quite eroded ones, have well-established museums that provide tuition regarding the fundamental importance of impact as well as the regional geology, geography, and environmental evolution. Examples are the Meteor Crater (Arizona) and Ries Crater (southern Germany) museums, exhibits in the Rochechouart Structure in southern France, in the Lockne Structure in Sweden, and in the Tswaing Crater of South Africa. Such exhibits may involve not just impact-related displays, but could also cover astronomical aspects such as the nature of the projectiles (asteroids and comets, their orbits, and their reservoirs). This can also include the target geology and any geographic aspect of a crater region, biological and hydrological, in fact, any environmental aspects of importance to the region, as well as paleo-environmental records that have accumulated within the closed crater structures 


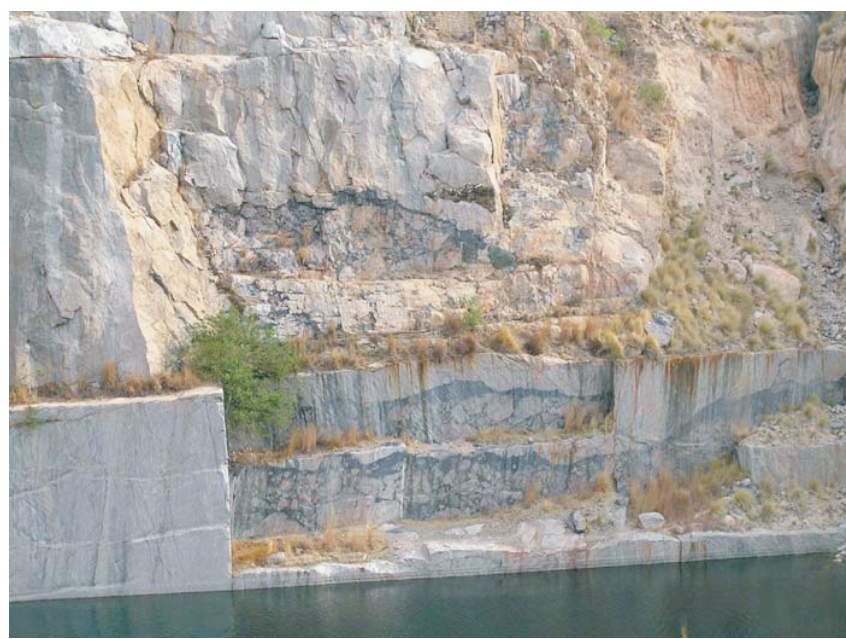

Figure 18. Leeukop quarry, $2 \mathrm{~km}$ north of the town of Paris, is one of the many dimension stone quarries that were operated in the 1980s and 1990s in the Vredefort Dome area. This quarry displays massive pseudotachylitic breccia and provides a glimpse of the geologic setting of mid-crustal granite-gneiss.

that were well protected since impact, and may provide long-term and very detailed information about paleo-climate.

Notably, ICDP drilling of impact structures has in some recent cases included paleo-environmental analysis as one of the two prime objectives (besides furthering the understanding of the impact process). Moreover, well-exposed crater structures can provide excellent geological laboratories and education sites, as already utilized by the Apollo astronauts who trained in the Meteor and Ries crater structures, or by the numerous firstyear students from South African universities, who have received for decades some of their geological motivation in the Tswaing Crater. Terrestrial impact structures are currently our only site laboratories for impact-geological investigations. As mentioned above, much more can be learned from detailed structural, stratigraphic, geophysical, and other scientific investigation.

A number of impact structures are also used as water reservoirs (Boltysh in Ukraine, or Manicouagan, Canada), or as a fishing resource (Bosumtwi, Ghana - although this case is of great concern due to overfishing of this lake), and can provide hydropower (Manicouagan). Dimension stone quarrying of impactites and related rocks may be an attractive economic spin-off. Both country rock (e.g., Vredefort, South Africa: the African Juparana [trade name] is the Archean granitegneiss and migmatite that was uplifted from midcrustal depth in the central uplift structure) and impactite (Rochechouart, France and Ries Crater, Germany - where both secular and religious buildings were constructed with impactite of the suevite type; Lonar Crater, India, where many religious constructions have been built with impact breccia) have been exploited - and in the process provide exceptional exposure, such as the many dimension stone quarries in the Vredefort Dome (Dressler and Reimold 2004; figure 18). And finally, commodities such as bentonite, other clay minerals, or coal may occur in impact structures both as part of the impact stratigraphy or as post-impact crater fill.

\section{Concluding remarks}

This short review of impact cratering and impact geology issues is intended as a first introduction to the topic for interested persons, but it is also hoped that it will ensure that a broad readership will take note of this fundamental process with implications for a range of geoscience disciplines. In particular, undergraduate teaching must contain a component about this fundamental and universal process. The selection of references provided should facilitate to obtain access to further information, but readers are also invited to contact the authors for more details.

\section{Acknowledgements}

We appreciate the reviews by Philippe Claeys, David King, and Christian Koeberl, as well as the editorial input from Hetu Sheth, all of whom significantly improved the manuscript.

\section{References}

Addison A D, Brumpton G R, Vallini D A, McNaughton N J, Davis D W, Kissin S A, Fralick P W and Hammond A L 2005 Discovery of distal ejecta from the 1850 Ma Sudbury impact event; Geology 33 193-196.

A'Hearn M F A, Belton M J S, Delamere W A, Kissel J, Klaasen K P, McFadden L A, Meech K J, Melosh H J, Schultz P H, Sunshine J M, Thomas P C, Veverka J, Yeomans D K, Baca M W, Busko I, Crockett C J, Collins S M, Desnoyer M, Eberhardy C A, Ernst C M, Farnham T L, Feaga L, Groussin O, Hampton D, Ipatov S I, Li J-Y, Lindler D, Lisse C M, Mastrodemos N, Owen W M, Richardson J E, Wellnitz D D and White R L 2005 Deep Impact: Excavating Comet Tempel 1; Science 310 (5746) 258-264, doi: $10.1126 /$ science.1118923.

Alvarez L W, Alvarez W, Asaro F and Michel H V 1980 Extraterrestrial cause for the Cretaceous-Tertiary extinction; Science 208 1095-1108.

Arenillas I, Arz J A, Grajales-Nishimura J M, MurilloMuneton G, Alvarez W, Camargo-Zanoguera, Molina E and Rosales-Domínguez C 2006 Chicxulub impact event is Cretaceous/Paleogene boundary in age: New micropaleontological evidence; Earth Planet. Sci. Lett. 249 241-257.

Arrhenius S 1903 Die Verbreitung des Lebens im Weltenraum; Die Umschau 7 481-485. 
Baegi M B 1996 Preliminary investigation of circular structures in eastern Tibisti, south-central Libya and their significance in radioactive mineral exploration; Technika Pszukiwań Geologicznych Geosynoptyka I Geotermia, No 2/96 35-43.

Baldwin R 1949 The Face of the Moon (Chicago: Univ. of Chicago) 239pp.

Becker L, Poreda R J, Hunt A G, Bunch T E and Rampino M 2001 Impact event at the Permian-Triassic boundary, Evidence from extraterrestrial noble gases in fullerenes; Science 291 1530-1533.

Becker L, Poreda R J, Basu A R, Pope K O, Harrison T M, Nicholson C and Iasky R 2004 Bedout: A possible End-Permian impact crater offshore of northwestern Australia; Science 304 1469-1476.

Boslough M B, Crawford D A, Robinson A C and Trucano T G 1994 Watching for fireballs on Jupiter; EOS Trans. Amer. Geophys. Union 75(27) 305-310.

Brownlee D E, Tsou P, Anderson J D, Hanner M S, Newburn R L, Sekanina Z, Clark B C, Hörz F, Zolensky M E, Kissel J, McDonnell J A M, Sandford S A and Tuzzolino A J 2003 Stardust: Comet and interstellar dust sample return mission; J. Geophys. Res. 108 E10 doi: 10.1029/2003JE002087.

Cameron A G W and Ward W R 1976 The origin of the Moon (abstract) Lunar Science VII (Houston: Lunar and Planetary Institute) 120-122pp.

Canup R M 2004a Dynamics of lunar formation; Annual Review of Astronomy and Astrophysics 42 441-475, doi: 10.1146/annurev.astro.41-082201.113457.

Canup RM 2004b Simulations of a late lunar-forming impact; Icarus 168 433-456, doi: 10.1016/j.icarus.2003. 09.028 .

Chadwick B, Claeys P, Simonson B M 2001 New evidence for a large Palaeoproterozoic impact: spherules in a dolomite layer in the Ketilidian orogen, South Greenland; J. Geol. Soc. London 158 331-340.

Chakrabarti R and Basu A R 2006 Trace element and isotopic evidence for Archean basement in the Lonar crater impact breccia, Deccan Volcanic Province; Earth Planet. Sci. Lett. 247 197-211.

Chapman C R 2004 The hazard of near-Earth asteroid impacts on earth; Earth Planet. Sci. Lett. 222 1-15.

Chapman C R and Morrison D 1994 Impacts on the earth by asteroids and comets: Assessing the hazard; Nature $36733-40$.

Cockell C S and Lee P 2002 The biology of impact craters a review; Biol. Rev. 77 279-310.

Dietz R S 1947 Meteorite impact suggested by orientation of shatter cones at the Kentland, Indiana, disturbance; Science $10542-43$.

Dietz R S 1959 Shatter cones in cryptoexplosion structures (Meteorite impact); J. Geol. 67 496-505.

Dressler B O and Reimold W U 2004 Order or Chaos? Origin and mode of emplacement of breccias in floors of large impact breccias; Earth Sci. Rev. 67 $1-60$.

El-Baz F and Ghoneim E 2006 Veiled crater in the eastern Sahara; The Planetary Report XXVI No 4 July/August $200610-15$.

Erwin D H 2001 Lessons from the past: Biotic recoveries from mass extinctions; Proc. Nat. Acad. Sci. 98(10) 5399-5403.

Farley K A, Montanari A, Shoemaker E M and Shoemaker C S 1998 Geochemical evidence for a comet shower in the late Eocene; Science 280 1250-1253.

French B M and Short N M (eds) 1968 Shock Metamorphism of Natural Materials (Baltimore: Mono Book Corp.) 644pp.
French B M 1998 Traces of catastrophe: A handbook of shock-metamorphic effects in terrestrial meteorite impact structure: LPI Contribution 954, Lunar and Planetary Institute, Houston, 120pp.

Gibson R L and Reimold W U 2001 The Vredefort impact structure: South Africa (the scientific evidence and a twoday excursion guide); Memoir 92 Council for Geoscience Pretoria 110pp.

Gladman B, Dones L, Levison H F and Burns J A 2005 Impact seeding and reseeding in the inner solar system; Astrobiology 5 483-496.

Grajales-Nishimura J M, Cedillo-Pardo E, RosalesDomínguez C, Morán-Zenteno D J, Alvarez W, Claeys P, Ruíz-Morales, García-Hernández J, Padilla-Avila P and Sánchez-Ríos A 2000 Chicxulub impact: The origin of reservoir and seal facies in the southeastern Mexico oil fields; Geology 28 307-310.

Glikson A Y and Haines P W 2005 Shoemaker Memorial Issue on the Australian impact record; Australian J. Earth Sci. 52 798pp.

Gohn G S, Koeberl C, Miller K G, Reimold W U, Cockell C S, Horton J W Jr, Sanford W E and Voytek M A 2006 Chesapeake Bay impact structure drilled; EOS Trans Amer. Geophys. Union 87 349-355.

Gradstein F M, Ogg J G, Smith A G, Bleeker W and Lourens L J 2004 A new Geological Time Scale, with special reference to Precambrian and Neogene; Episodes 27 83-100.

Grady M M, Hutchison R, McCall G J H and Rothery D A 1998 Meteorites: Flux with Time and Impact Effects; Geol. Soc. London, Special Publication 140 278pp.

Grieve R A F 2005 Economic natural resource deposits at terrestrial impact structures; Mineral Deposits and Earth Evolution (eds) McDonald I, Boyce A J, Butler I B, Harrington R J and Polya D A, Geol. Soc. London, Special Publication 248 1-29.

Grieve R A F and Masaitis V L 1994 The economic potential of terrestrial impact craters; Int. Geol. Rev. 36 399-420.

Grieve R A F 2006 Large-scale impacts and the evolution of the Earth's crust: The early years; In: Processes on the Early Earth (eds) Reimold W U and Gibson R L, Geol. Soc. Amer. Special Paper 405 23-32.

Grieve R A F, Stöffler D and Langenhorst F 1996 Shock metamorphism in nature and experiment II. Significance in geoscience; Meteoritics Planet. Sci. 31 6-35.

Grieve R A F, Cintala M J and Therriault A M 2006 Largescale impacts and the evolution of the Earth's crust: The early years; In: Processes on the Early Earth (eds) Reimold W U and Gibson R L, Geol. Soc. Amer. Special Paper 405 23-31.

Halliday A N 2006 The origin of the Earth - What's new?; Elements 2 205-210.

Hartmann W K and Davis D R 1975 Satellite-sized planetesimals and lunar origin; Icarus 24 504-515.

Hayward C L, Reimold W U, Gibson R L and Robb L J 2005 Gold mineralisation within the Witwatersrand Basin, South Africa: evidence for a modified placer origin, and the role of the Vredefort impact event; In: Mineral Deposits and Earth Evolution (eds) McDonald I, Boyce A J, Butler I B, Herrington R J and Polya D A, Geol. Soc. London, Special Publication 248 $31-58$.

Hildebrand A R, Penfield G T, Kring D A, Pilkington M, Carmargo-Zanoguera A, Jacobson S P and Boynton W V 1991 Chicxulub crater: a possible Cretaceous/Tertiary boundary impact crater on the Yucatán Peninsula Mexico; Geology 19 867-871. 
Huffman A R and Reimold W U 1996 Experimental constraints on shock-induced microstructures in naturally deformed silicates; Tectonophys. 256 165-217.

Hofmann A, Reimold W U and Koeberl C 2006 Archean spherule layers from the Barberton Mountain Land: A critical assessment; In: Processes on the Early Earth (eds) Reimold W U and Gibson R L, Geol. Soc. Amer. Special Paper 405 33-56.

Kaiho K, Kajiwara Y, Nakano T, Miura Y, Kawahata H, Tazaki K, Ueshima M, Chen Z and Shi G R 2001 EndPermian catastrophe by a bolide impact: Evidence of a gigantic release of sulfur from the mantle; Geology 29 815-818.

Keller G, Stinnesbeck W, Adatte T and Stüben D 2004 More evidence that the Chicxulub impact predates the K-T boundary mass extinction; Meteoritics Planet. Sci. 39 1127-1144.

Kenkmann T, Hornemann U and Stöffler D 2000 Experimental generation of shock induced pseudotachylites along lithological interfaces; Meteoritics Planet. Sci. 35 1275-1290.

Koeberl C 1997 Impact cratering: the mineralogical and geochemical evidence; Oklahoma Geological Survey Circular $10030-54$.

Koeberl C 2002 Mineralogical and geochemical aspects of impact craters; Min. Mag. 66 745-768.

Koeberl C 2004 Remote sensing studies of impact craters: how to be sure?; Comptes Rendus Geoscience $\mathbf{3 3 6}$ 959-961.

Koeberl C 2006 The record of impact processes on the early Earth - A review of the first 2.5 billion years; In: Processes on the Early Earth (eds) Reimold W U and Gibson R L (Boulder Colorado: Geological Society of America) Special Paper 405 1-22pp.

Koeberl C, Reimold W U and Boer R H 1993 Geochemistry and mineralogy of Early Archean spherule beds, Barberton Mountain Land, South Africa: Evidence for origin by impact doubtful; Earth Planet. Sci. Lett. 119 441-452.

Koeberl C and MacLeod (eds) 2002 Catastrophic Events and Mass Extinctions: Impacts and Beyond (Boulder Colorado: Geological Society of America) Special Paper 356 746pp.

Koeberl C, Gilmour I, Reimold W U, Claeys P and Ivanov B 2002 Comment on "End-Permian catastrophe by bolide impact: Evidence of a gigantic release of sulfur from the mantle" by Kaiho K et al (Geology, 29, 815-818, 2001); Geology 30 855-856. (ICRG No. 31).

Koeberl C, Reimold W U and Plescia J 2005 BP and Oasis impact structures, Libya: remote sensing and field studies; In: Impact Tectonics (eds) Koeberl $\mathrm{C}$ and Henkel $\mathrm{H}$ (Berlin-Heidelberg-New York: Springer-Verlag) Impact Studies Series 8 161-190.

Kring D A, Horton J W Jr and Cannon W F 2006 Discovery of the Sudbury impact layer in Michigan, USA (abstract); Meteoritics Planet. Sci. 41 (Suppl.) A100p.

Kumar P S 2005 Structural effects of meteorite impact on basalt: Evidence from Lonar crater; India; J. Geophys. Res. 110, B12402, doi:10.1029/2005JB003662.

Langenhorst F and Deutsch A 1998 Minerals in terrestrial impact structures and their characteristic features; In: Mineral matter in Space, mantle, Ocean Floor, Biosphere, Environmental Management and Jewellery (ed.) Marfunin A S (Berlin-Heidelberg: Springer-Verlag) Advanced Mineralogy 3 95-119.

Langenhorst F, Poirier J-P, Deutsch A and Hornemann U 2002 Experimental approach to generate shock veins in single crystal olivine by shear heating; Meteoritics Planet. Sci. 37 1541-1553.
Langenhorst F, Kyte F T and Retallack G J 2005 Reexamination of quartz grains from the Permian-Triassic boundary section at Graphite Peak Antarctica; Lunar and Planetary Science Conference XXXVI, Lunar and Planetary Institute, Houston CD-ROM abstract No. 2358, 2pp.

MacLeod N, Rawson P F, Forey $\mathrm{P}$ L, Banner $\mathrm{F} T$, Boughager-Fadel M K, Brown $\mathrm{P} R$, Burnett $\mathrm{J}$ A, Chambers P, Culver S, Evans S E, Jeffery C, Kaminski M A, Lord A R, Milner A C, Milner A R, Morris N, Owen E, Rosen B R, Smith A B, Taylor P D, Urquhart E and Young J R 1997 The CretaceousTertiary biotic transition; J. Geol. Soc. 154 265-292.

Maré L P, Eriksson P G and Améglio L 2006 A paleomagnetic study of the lower part of the Palaeoproterozoic Waterberg Group, South Africa; J. Afr. Earth. Sci. 44 21-36.

Mark K 1987 Meteorite Craters (Tucson: The University of Arizona Press) 288 pp.

Masaitis V L 1998 Diamond-bearing impactites of the Popigai astrobleme (in Russian) (Moscow: VSEGEI Press) 178pp.

McDonald I 2002 Clearwater East impact structure: a reinterpretation of the projectile using new platinum-group element data from meteorites; Meteoritics Planet. Sci. 37 $459-464$.

McKay D S, Gibson E K Jr, Thomas-Keptra K L, Vali H, Romanek C S, Clemett S J, Chillier X D F, Maechling C R and Zare R N 1996 Search for past life on Mars: Possible relic biogenic activity in Martian meteorite ALH 84001; Science 273 924-930.

Melosh H J 1989 Impact Cratering: A Geological Process (Oxford: Oxford Univ. Press) 245pp.

Montanari A and Koeberl C 2000 Impact Stratigraphy The Italian Record. Lecture Notes in Earth Sciences 93 (Heidelberg-Berlin: Springer-Verlag) 364 pp.

Morishima R and Watanabe S 2004 Co-accretion of the Earth-Moon system after the giant impact: reduction of the total angular momentum by lunar impact ejecta; Icarus 168 60-79.

Mory A J, Iasky R P, Glikson A Y and Pirajno F 2000 Woodleigh, Carnarvon basin, Western Australia: A new $120 \mathrm{~km}$ diameter impact structure; Earth Planet Sci. Lett. 177 119-128.

Müller R D, Goncharov A and Kritski A 2005 Geophysical evaluation of the enigmatic Bedout basement high, offshore northwestern Australia; Earth Planet Sci. Lett. 237 264-284.

Müller-Mohr V 1992 Breccias in the basement of a deeply eroded impact structure Sudbury, Canada; Tectonophysics 216 219-226.

Muñoz-Espadas M-J, Martinez-Frias $J$ and Lunar R 2003 Main geochemical signatures related to meteoritic impacts in terrestrial rocks: a review; In: Impact Markers in the Stratigraphic Record (eds) Koeberl C and Martinez-Ruiz C (Heidelberg-Berlin: Springer-Verlag) Impact Studies 3 65-90pp.

Norris R and Stootman F (eds) 2004 "Bioastronomy 2002: Life Among the Stars" (San Francisco: Astronomical Society of the Pacific) 299-304.

Oreskes N (ed.) 2003 Plate Tectonics: An Insider's History of the Modern Theory of the Earth (Boulder, Colorado: Westview Press) 448pp.

Osae S, Misra C, Koeberl C, Sengupta D and Ghosh S 2005 Target rocks, impact glasses, and melt rocks from the Lonar impact crater, India: Petrography and geochemistry; Meteoritics Planet. Sci. 40 1473-1492.

Paillou P H, Rosenqvist A, Malézieux J-M, Reynard B, Farr T and Heggy E 2003 Discovery of a double impact 
crater in Libya: the astrobleme of Arkenu; Comptes Rendus Acad. Sci. Paris Geosci. 335 1059-1069.

Palme H 1982 Identification of projectiles of large terrestrial impact craters and some implications for the interpretation of Ir-rich Cretaceous/Tertiary boundary layers; In: Geological Implications of Impacts of Large Asteroids and Comets on Earth (eds) Silver L T and Schultz P H, Geol. Soc. Amer. Special Paper 190 223-233.

Pati J K 2005 The Dhala structure, Bundelkhand craton, Central India - a new large Paleoproterozoic impact structure (abstract); Meteoritics Planet. Sci. 40 (Suppl.) p. A121.

Pati J K, Reimold W U and Arvind 2006a Ballen quartz in impact melt rock from the Dhala impact structure, Bundelkhand Craton, Central India, (abstract) 'ESLAB40: First International Conference on Impact Cratering in the Solar System', ESTEC, Noordwijk, The Netherlands.

Pati J K, Nadeem M, Kundu R, Bhusan R and Reimold W U 2006b Monomict impact breccia from Dhala structure, Archean Bundelkhand Craton, Central India: Macro- and mesoscopic impact-induced deformation (abstract); Meteoritics Planet. Sci. 41 (Suppl.) A139pp.

Rampino M R 1999 Impact crises, mass extinctions, and galactic dynamics: The case for a unified theory; In: Large Meteorite Impacts and Planetary Evolution II (eds) Dressler B O and Sharpton V L, Geol. Soc. Amer. Special Paper 339 241-248.

Reimold W U 1995 Pseudotachylites in impact structures generation by friction melting and shock brecciation? A review and discussion; Earth Sci. Rev. 39 247-265.

Reimold W U 1998 Exogenic and endogenic breccias: a discussion of major problematic; Earth Sci. Rev. 43 25-47.

Reimold W U 2006 Impact structures in South Africa; In: The Geology of South Africa (eds) Johnson M R, Anhaeusser C R and Thomas R J, Geol. Soc. S. Africa and Council for Geoscience Pretoria, Chapter 30, in press.

Reimold W U and Koeberl C 2000 Critical comment on: "A J Mory et al, Woodleigh, Carbarvon basin, Western Australia: A new $120 \mathrm{~km}$ diameter impact structure." Earth Planet. Sci. Lett. 184 353-357.

Reimold W U and Gibson R L 2005a A Meteorite Impact the Danger from Space and South Africa's Mega-Impact, the Vredefort Structure (Johannesburg, South Africa: Chris van Rensburg Publ. (Pty) Limited) 319pp.

Reimold W U and Gibson R L 2005b "Pseudotachylites" in large impact structures; In: Impact Tectonics (eds) Koeberl C and Henkel H (Berlin-Heidelberg-New York: Springer-Verlag) Impact Studies Series 8 1-53pp.

Reimold W U, Trepmann C and Simonson B 2006 Discussion - Impact origin of the Ramgarh Structure, Rajasthan: Some new evidences by Sisodia et al 2006; J. Geol. Soc. India 68 561-563.

Reimold W U, Koeberl C, Gibson R L and Dressler B O 2005 Economic mineral deposits in impact structures: a review; Impact Tectonics (eds) Koeberl $\mathrm{C}$ and Henkel $\mathrm{H}$ (Heidelberg-Berlin: Springer-Verlag) 479-552.

Renne P R, Reimold W U, Koeberl C, Hough R and Claeys P 2002 Critical comment on: "K-Ar evidence from illitic clays of a Late Devonian age for the $120 \mathrm{~km}$ diameter Woodleigh impact structure Southern Carnarvon Basin, Western Australia" (eds) Uysal I T et al, Earth Planet. Sci. Lett. 201 247-252.

Renne P R, Melosh H J, Farley K A, Reimold W U, Koeberl C, Rampino M R, Kelly S P and Ivanov B A 2004 Is Bedout an impact crater? Take 2; Science 306 610-611.
Retallack G J, Seyedolali A, Krull E S, Holser W T, Ambers C A and Kyte F T 1998 Search for evidence of impact at the Permian-Triassic boundary in Antarctica and Australia; Geology 26 979-982.

Schopf J W 2006 The first billion years: When did life emerge? Elements 2 229-233.

Schubert G, Turcotte D L and Olson P 2001 Mantle Convection in the Earth and Planets (Cambridge: Cambridge University Press) 940pp.

Schulte P, Speijer R, Mai H and Kontny A 2006 The Cretaceous-Paleogene $(\mathrm{K} / \mathrm{P})$ boundary at Brazos (Texas): sequence stratigraphy, depositional events and the Chicxulub impact Sediment; Geology 184 77-109.

Shoemaker E M 1963 Impact mechanics at Meteor Crater, Arizona; Moon, Meteorites, and Comets (eds) Middlehurst B M and Kuiper G P (Chicago: University of Chicago) 301-336pp.

Simonson B M and Glass B P 2004 Spherule layers - records of ancient impacts; Annu. Rev. Earth Planet. Sci. 32 329-361.

Sisodia M S, Lashkari G and Bhandari N 2006a Impact origin of the Ramgarh Structure, Rajasthan: Some new evidences; J. Geol. Soc. India 67 423-431.

Sisodia M S, Lashkari G and Bhandari N 2006b Reply [to Discussion of Reimold et al 2006]; J. Geol. Soc. India 68 563-565.

Smit J and Hertogen J 1980 An extraterrestrial event at the Cretaceous-Tertiary boundary; Nature 285 198-200.

Smit J 1999 The global stratigraphy of the CretaceousTertiary boundary impact ejecta; Annu. Rev. Earth Planet. Sci. 27 75-113.

Son T H and Koeberl C 2005 Chemical variation within fragments of Australasian tekite; Meteoritics Planet. Sci. 40 805-815.

Spray J G 1998 Localized shock- and friction-induced melting in response to hypervelocity impact; In: Meteorites: Flux with Time and Impact Effects (eds) Grady M M, Hutchison R, McCall G J H and Rothery D A, Geol. Soc. London Special Publication 140 195-204.

Stöffler D 1972 Deformation and transformation of rockforming minerals by natural and experimental shock processes. I. Behaviour of minerals under shock compression; Fortschritte der Mineralogie 49 50-113.

Stöffler D and Langenhorst F 1994 Shock metamorphism of quartz in nature and experiment: I. Basic observations and theory; Meteoritics 29 155-181.

Stöffler D and Reimold W U 2006 Geologic setting, properties, and classification of terrestrial impact formations; In: Papers to First International Conference on Impact Cratering in the Solar System, 8-12 May 2006, Noordwijk Netherlands CD-ROM, ESLAB-40, WPP-266, 6 pp.

Stöffler D, Keil K and Scott E R D 1991 Shock metamorphism of ordinary chondrites; Geochim. Cosmochim. Acta $553845-3867$.

Stöffler D, Artemieva N A, Ivanov B A, Hecht L, Kenkmann T, Schmitt R T, Tagle R A and Wittmann A 2004 Origin and emplacement of the impact formations at Chicxulub, Mexico, as revelaed by the ICDP deep drilling at Yaxcopoil-1 and by numerical modeling; Meteoritics Planet. Sci. 39 1035-1067.

Stöffler D, Meyer C, Fritz J, Horneck G, Möller R, Cockell C, Ott S, de Vera J P, Hornemann U and Artemieva N A 2006 Impact experiments in support of "Lithopanspermia"; The route from Mars to Earth; 3\%th Lunar Planet. Sci. Conf., Houston 1551 2pp.

Tagle R A and Claeys P 2005 An Ordinary Chondrite Impactor for the Popigai Crater, Siberia; Geochim. Cosmochim. Acta 69 2877-2889. 
Taylor S R 1992 Solar System Evolution: A New Perspective (New York: Cambridge Univ.) 307pp.

Treiman A H 1998 The history of Allan Hills 84001 revisited: Multiple shock events; Meteoritics Planet. Sci. 33 $753-764$.

Urrutia-Fucugauchi F, Morgan J, Stöffler D and Claeys P 2004 The Chicxulub Scientific Drilling Project (CSDP) Meteoritics Planet. Sci. 39 787-790.

Uysal I T, Golding S D, Glikson A Y, Mory A J and Glikson M $2001 \mathrm{~K}$-Ar evidence from illitic clays of a late Devomian age for the $120 \mathrm{~km}$ diameter Woodleigh impact structure, Southern Carnarvon basin, Western Australia; Earth Planet. Sci. Lett. 192 281-289.

Wegener A 1915 Braunschweig: Die Entstehung der Kontinente und Ozeane (Braunschweig: Vieweg-Verlag) $94 \mathrm{pp}$.

Wegener A 1921 Die Entstehung der Mondkrater (Braunschweig: Vieweg-Verlag) 48pp.
Westall F, de Vries S T, Nijman W, Rouchon V, Orberger B, Pearson V, Watson J, Verchovsky A, Wright I, Rouzoud J-N, Marchesini D and Severine A 2006 The 3.466 Ga, 'Kitty's Gap Chert', an early Archean microbial ecosystem; In: Processes on the Early Earth (eds) Reimold W U and Gibson R L (Colorado: GSA) Special Paper 405 105131.

Wieland F, Reimold W U and Gibson R L 2006 New observations on shatter cones in the Vredefort impact structure, South Africa, and an evaluation of current models for shatter cone formation; Meteoritics Planet. Sci. 41 (in press).

Wilhelms D E 1987 The Geologic History of the Moon; US Geological Survey Professional Paper 1348 302pp and plates.

Wu S 1987 The Duolon impact crater, China: Abstracts; International Geological Correlation Project 199 Meeting March 3-4, 1987, Beijing, China, 1p. 